\title{
Agricultural biogas production in Germany - from practice to microbiology basics
}

\author{
Michael Lebuhn ${ }^{1 *}$, Bernhard Munk ${ }^{1}$ and Mathias Effenberger ${ }^{2}$
}

\begin{abstract}
Worldwide, anaerobic digestion for sanitation and utilization of the produced biogas as energy carrier have a long-standing history. Concomitantly, digested residues from biogas plants are utilized as valuable fertilizers in crop production. In Germany, guaranteed prices for electricity generated from renewable sources pushed the number of biogas plants from about 140 in 1992 to about 7,720 by the end of 2013, and the share of electricity supply from biogas close to $4.5 \%$. In the midterm, biogas is given considerable potential to fill up the residual load from electricity generation based on wind and photovoltaic. In this review, we give an overview of the state-of-the-art of biogas technology for energy supply from agricultural inputs, based mainly on the situation in Germany. Focus is placed on the monitoring and control (M\&C) of biogas plants as a means of meeting the growing demands for productivity and reliability of biogas supply. We summarize prominent factors for the stability and productivity of the anaerobic digestion (AD) process, and present latest findings about molecular biology tools, bioindicators, the 'metabolic quotient' and CDNA/DNA ratios for process analysis. In view of the large diversity of agricultural biogas installations, we discuss the cost-benefit ratio of $M \& C$ effort and equipment. In the light of the transformation of the energy system in Germany towards renewable sources ('Energiewende'), we give an outlook on prospects and concepts for the future role of biogas technology in agriculture and energy supply. We also address recent misguided developments, as the sustainable development of biogas technology in agriculture can only be realized within the ecological, economical, and social boundaries of underlying agro-ecological systems.
\end{abstract}

Keywords: Agriculture; Biogas production; Process control; Engineering; Microbiology; Molecular biology; Early-warning; Energy supply on demand

\section{Review}

The most prominent beneficial features of the anaerobic digestion (AD) process are generation of biogas as a renewable energy carrier based on solar energy stored in biomass and hygienization of the input material during the treatment. Although it turns out from the following section that making use of hygienization is invaluable and has a long-standing history, the focus of this manuscript is on energy supply from biogas. The intent is to highlight the role of biogas production in a sustainable renewable energy framework in order to counteract consequences of the unsustainable resource management in the last century. Moreover, intensifying

\footnotetext{
* Correspondence: michael.lebuhn@|lf.bayern.de

'Bavarian State Research Center for Agriculture, Department for Quality

Assurance and Analytics, Lange Point 6, 85354 Freising, Germany

Full list of author information is available at the end of the article
}

sustainable energy use has gained particular importance since the recent catastrophes with nuclear energy.

This article builds on recent reviews by Weiland [1] and Braun et al. [2] on the state of biogas production in 2010, with emphasis on the development in Germany. In the last few years, the role of biogas as envisaged in the German renewable energy concept (see 'The role of biogas within the German energy supply system' section) has fuelled respective research and practical initiatives, resulting in an enormous increase of scientific perception and technical know-how. Such new aspects, insights, and developments, particularly from the side of microbiology, are integrated into the current review. They modify or change some established opinions and open the doors toward new biotechnological developments, some of which are introduced in more detail. (c) 2014 Lebuhn et al.; licensee Springer. This is an Open Access article distributed under the terms of the Creative Commons Attribution License (http://creativecommons.org/licenses/by/4.0), which permits unrestricted use, distribution, and reproduction in any medium, provided the original work is properly credited. 


\section{Background}

In this section, a brief history of biogas production is compiled from information publicly accessible in the internet [3-7]. The utilization of biogas from AD appears to have a long history. There is evidence from anecdotes that biogas was used already 3,000 years ago for heating bathing water in Assyria. Marco Polo reported that covered sewage tanks, obviously built for biogas production some 2,000 to 3,000 years ago, were mentioned in ancient Chinese literature. From these reports it appears that the utility of biogas as energy carrier and of the process for hygienic improvement has been recognized very early.

In Europe, the earliest reports mentioning the flammable biogas date back to the 17th century. In the 18th century, it became a matter of scientific research. It was found that the amounts of flammable gas and decaying organic matter were correlated, that the process developed under anaerobic conditions and that the flammable component of the gas produced in anaerobic digestion of cattle manure was methane.

Further developments intended to make use of the biogas process on a bigger scale. The first biogas plant was built in India in 1859 for the treatment of sewage from a leper colony, making use of the hygienizing feature of the process and the energy content of the gas. Sewage treatment plants were constructed subsequently in England and in Germany utilizing the produced biogas first to illuminate street lanterns, then for heating and later to feed the public gas supply and fuel vehicles in the early 20th century.

Early in the 20th century, scientific progress boosted biogas technology worldwide. It was discovered that microorganisms carry out the biogas process and are responsible for methane production. In the USA in the 1930s, ideas were developed to utilize cellulose-rich waste for biogas production. Methane production from farm manure was developed in India at that time, and prosperous families built some rural biogas plants in China. In Europe, including colonies, the first agricultural biogas plants were constructed in Algeria and, based on these experiences, this type was spread in southern France and Italy after World War II. In Germany, the technology used in agricultural biogas production was initially adopted from anaerobic municipal wastewater and sewage sludge treatment plants.

In 1940 due to the increasing energy demand, first attempts were made to intensify gas production and improve process efficiency of the AD process by adding organic residues such as fats. During World War II and a limited time thereafter, agricultural biogas production was promoted to supply energy carriers which were in urgent need. However, when fossil energy carriers, particularly mineral oil, were at disposal and became cheaper, agricultural biogas production largely faded in Europe.
Only two of initially fifty plants continued to operate. The revival of agricultural biogas production has been brought about by steadily increasing prices of fossil energy carriers, oil crises, 'peak oil', and the growing concern about the consequences of intensified greenhouse gas emissions from fossil fuel burning and unsustainable use of resources.

In India and China, the number of small biogas plants particularly for rural households strongly increased in the 1970s due to government development programs and subsidies. Meanwhile, more than a million small biogas digesters exist in India and more than seven million of these plants exist in China, where about 28 million households are reported to use biogas, as of 2008. While initially septic tanks were used, this type was soon replaced by the typical dome-shaped constructions. Current developments include the adoption of European industry-scale biogas technology.

In Europe and particularly in Germany, due to the increasing energy demand and prices, more industry-scale biogas plants were constructed in the 1980s, when a boom of agricultural biogas production was initiated by the Act on Feed-In of Electricity (StrEG) in 1991 and the Act on Renewable Energy (EEG) in 2000. With this legislative framework, renewable energies were given access to the electricity grid and competitiveness on the market. However, the excellent properties of biogas for energy storage and use on demand were neglected, initially. This item is picked up in the sections 'The role of biogas within the German energy supply system' and 'Prospects and concepts'.

Guaranteed prices for electricity generated from biogas pushed the number of biogas plants in Germany from 75 in 1985 to more than 400 in 1997, and currently about 7,720 [8]. Besides the generation of electricity, the digested residue of the $\mathrm{AD}$ process is used as valuable fertilizer in the agricultural nutrient cycle. The heat output from co-generation units is either used on site or sent to district-heating systems. After upgrading the biogas to 'bio-methane', this can be fed into the gas grid to substitute natural gas. In the following section, the German energy policy for the coming decades and the conceptual integration of biogas production are described, including actual biotechnical developments and optimization potentials.

\section{The role of biogas within the German energy supply system}

As outlined in the 'Background' section, the pressing issue of global warming and the nuclear incident in Fukushima as of 2011 prompted the German government to change its concept for the development of the energy supply system. The catchword 'Energiewende' was coined, specifying the roadmap towards a substantial reduction of the use of fossil and nuclear energy 
carriers, in favor of so-called renewable energy sources (RES).

According to the German 'National Renewable Energy Action Plan' (NREAP) [9], 18\% of gross energy consumption shall be covered by RES in 2020, an increase of ca. $8 \%$ compared with the figure of 2009 . Until 2050, at least $80 \%$ of greenhouse gas emissions shall be avoided compared to the emissions in 1990. Sixty percent of the gross energy demand and $80 \%$ of the gross electricity consumption shall be provided by RES.

In the end of 2012, RES contributed 317.8 TWh (12.7\%) to the final gross energy supply in Germany. Within the segments electricity, heat and motor fuels, RES accounted for $45.1 \%$ (143.5 TWh), $43.5 \%$ (138.3 TWh), and $11.4 \%$ (36.1 TWh), and saved 337.9, 149.5 and 23.0 TWh primary fossil energy in these areas, respectively. Until 2020, the share of RES shall be increased in these segments to at least $35 \%, 14 \%$ and $10 \%$ of the final gross energy supply, respectively $[10,11]$. Following the 'Energiewende' roadmap, the NREAP foresees that by 2020 , the major part of electricity will be provided by wind energy (104.4 TWh versus 36.5 TWh in 2010), followed by bioenergy (non-fossil, 49.5 TWh versus $33.5 \mathrm{TWh}$ in 2010), photovoltaics (41.4 TWh versus 12.0 TWh in 2010) and hydropower (20.0 TWh versus 19.7 TWh in 2010). Geothermal and sea/tidal energy will contribute a minor portion $(<5 \mathrm{TWh})$. Biogas (including biogas derived from the biogenic fraction of waste) will make up at least a major part $(47.3 \%$ versus 41.5\% in 2010) of bioenergy [12].

The German Agency for Renewable Resources (FNR) estimated in 2011 that bioenergy from non-fossil biomass can supply $23 \%(1,640 \mathrm{PJ})$ of the German total energy demand (6,950 PJ) in 2050 [13]. In this figure, the FNR assigns the potential to energy crops that they can make up $45 \%$ of the bioenergy contribution in 2050, followed by forestry products (22\%), agricultural residues (18\%) and other biogenic waste or residues (15\%). More than $63 \%$ of the bioenergy might thus originate from agricultural sources, and this portion could be provided almost exclusively by biogas production. The low estimate of forestry without major increase is explained by the difficulty to digest lignocellulose fibers, but also by competing use of wood, e.g., as building material. Although the complete utilization of biowaste such as food leftovers is highly desirable and technological progress along with public efforts will increase the utilized portion to some extent, a major contribution cannot be expected to originate from this segment simply due to the necessity to avoid the production of biowaste. AD of organic waste requires additional measures since hygienization criteria imposed by European and national legislation must be met $[14,15]$.

However, these figures drawn by the FNR may change with the most recent political and economical developments [16]. The progressive implementation of RES into the energy supply system is sustained, with the development goal to cover $40 \%$ to $45 \%$ of the electric energy supply until 2025 and $55 \%$ to $60 \%$ until 2035 , but in the biomass sector priority is assigned to the utilization of agricultural residues and biogenic waste in additionally installed plants, whereas energy crops fall out of favor. Respective modifications in the forthcoming release of the EEG in 2014, e.g., of feed-in tariffs will most likely affect the composition of the future substrate spectrum of agricultural biogas plants. In this case, the abovementioned shortcomings of lignocellulose-rich biomass and of biowaste will be an aggravating issue.

Compared with photovoltaics and wind energy, the particular advantage of bioenergy is that produced biomass or reduced carbon compounds (see below) can be stored and are available on demand, whereas wind and sunlight are subject to weather and seasonal fluctuations. Besides providing some of the basal energy supply, the major contribution of bioenergy will therefore consist in filling energy supply gaps that arise if demand exceeds electricity supply from wind power and photovoltaics [17]. As specified later (see 'Prospects and concepts' section), temporary surplus production of electricity may also be converted to storable products such as methane by biogas upgrading ('biomethane') and so-called 'power-to-gas' technologies. These technologies are thus ideally suited to balance weather-dependent electricity production and oscillating energy demand.

\section{Agro-environmental and social aspects}

Large-scale biogas production may either be realized by governmental planning, irrespective of competitiveness, such as in the 1970s in China (see 'Background' section), or in a framework of competition on the market, possibly with initial subsidies to support the establishment of the technology as it was the case in Germany (see 'Background' section). As a consequence of the low milk prices, many dairy farms lost profitability. The biomass grown on this former pasture land could not be used for dairy feeding anymore. If the biomass is not used alternatively, e.g. for biogas production, the land would fall out of agronomical production. According to a recent prediction for Bavaria until $2020,165,500$ to 208,800 ha of permanent grassland will fall out of use, and 70,900 ha crop land will fall out of feed production [18]. If biomass utilization can be diverted to energy production and concomitantly generates income for the farmer, further cultivation of the grassland is justified. The term 'from farmer to energy entrepreneur' was coined for this development. However, it turned out that many factors, including economical, ecological, and social aspects influence the competitiveness and viability of this enterprise.

In a recent survey, 378,000 work places were assigned to renewable energies in Germany in 2012. Within these, 
129,000 fell upon the segment of bio-energy [19], of which 45,485 work places were counted in the biogas industry sector [8]. As a result of changes in the regulations and reductions in feed-in tariffs, the biogas industry had to cut jobs by nearly 18,000 in the last 2 years, and further job losses are expected for 2013. In accordance, business volume in the biogas sector fell from 8.3 billion $€$ in 2011 to 7.3 billion $€$ in 2012, and a further decrease to 6.9 billion $€$ in 2013 is predicted by the German Biogas Association [8]. For 2014, however, a slight upward trend is expected for this industry line.

Public acceptance is a major factor influencing the development of the agricultural biogas industry. Currently, more than half of the German agricultural biogas plants are in private hands. Therefore, economic considerations as well as acceptance by the neighborhood and the public in general are decisive factors for the success of a construction project, besides legal premises. Although recent surveys [20] attest overwhelming public compliance with the promotion of renewable energies, this acceptance can be significantly restrained in cases of personal concern due to 'Not-In-My-Backyard' considerations. It is thus advisable to involve the public from the beginning of a project, at best by building a participation cooperative and a structure that creates added value for the region [20].

The utilization of organic waste and agricultural residues for energy production is generally accepted and publically supported. Biogas production from animal manure has probably the longest history. Although complete utilization of liquid manure and dung from animal husbandry and fattening would be most desirable, excess production may not be usable as fertilizer in the farm or enterprise nutrient cycle. Transport of manure with high water content to neighbor buyers may not be economical. Utilization of animal manure for biogas production is an excellent option since it contains a broad spectrum of suitable $\mathrm{AD}$ microorganisms and buffer capacity stabilizing the process, and hygienization of the manure during the $\mathrm{AD}$ process is of ecological and socio-economic value [21]. However, covering the cost for construction and maintenance of biogas plants using animal manure solely is challenging due to the low methane yield of this input [22], and the nutrient cycling problem still remains. Liquid-solid-phase separation of the digestate may be an option if transportation of solids is economically viable and the internal nutrient cycles can be closed.

On a fresh matter basis, the methane yield from starchy energy crops is an order of magnitude higher than that of liquid manure. Currently, maize is the most productive and well-known crop, and is therefore used on more than $75 \%$ of the agricultural biogas plants in Germany, providing about $60 \%$ of the biogas energy [23]. Since it is not sustainable to build a crop sequence only on maize, alternatives to and combinations with this crop are studied intensively. Besides well-established crops such as different cereals, new energy crops are bred and tested, e.g., sorghum or perennial crops such as Sida hermaphrodita. As mentioned above, another option is the use of grassland for biogas production. However, what cannot be neglected and is now frequently criticized is the fact that the production of biogas from energy crops already requires substantial areas of cropland. For 2013, the FNR states that 1.157 million hectares of cropland were dedicated to the production of biogas. This is close to $10 \%$ of the available cropland in Germany. Since it is questioned whether the competing use of cropland for biogas instead of food or feed production is desirable and sustainable, balancing both production lines to counteract one-sided overproduction must be attempted.

When comparing electricity from biogas to other renewable and conventional energy carriers, it turns out that the environmental impacts of biogas plants can to a large part be attributed to crop production. In comparison to a reference system for electricity and heat supply based on fossil fuels, it appeared that specific eutrophication and acidification potentials for biogas from maize were significantly higher. However, with respect to energy consumption and greenhouse gas (GHG) emissions, energy supply from biogas resulted in considerably lower impacts [24]. Specific GHG emissions of biogas electricity can be extremely variable, particularly in dependence on the type of input materials, i.e., mainly energy crops or manure, and the utilization ratio for heat, as shown in studies of exemplary biogas installations in Bavaria [25]. Modeling the GHG balance of biogas from energy crops is limited by the very large uncertainty with respect to nitrous oxide emissions from cropland [26]. Dominant influencing technical factors on the GHG balance are methane emissions from open storage of digested residues and incomplete combustion in co-generation units [27]. Substantial emissions of methane from biogas plants due to leakage of digesters and pipes are limited to exceptional cases. Biogas systems for combined heat-and-power production based on energy crops have been criticized for their relatively high GHG mitigation cost in comparison to other bioenergy pathways such as short-rotation wood or straw [28].

As for Germany, due to the abovementioned limitations and concerns, it is doubtful whether the production of biogas from cropland will further be extended significantly and whether this is desirable, at last. In other countries, biogas crops have not played a comparable role yet due to their high production cost. What will be of increasing interest, though, is the integration of the existing capacity of biogas plants into the energy supply system. As outlined below, it is comparably easy and affordable to decouple the processes of biogas production and utilization on a daily basis to provide balancing power for the fluctuating energy output from wind and photovoltaic. 


\section{Process engineering and optimization}

Optimized AD process performance is a prerequisite of economically and ecologically sustained biogas plant operation. The 'hardware', design, and technology must provide optimum conditions for the microbial biocenosis that carries out the $\mathrm{AD}$ process. The weakest link of the intimately cooperating, stepwise syntrophic microbial nutrition chain determines process rate and efficiency. Since these syntrophic associations between methanogenic Archaea and certain bacteria are thriving at the limit of possible energy gain [29], process perturbation will typically affect these first, resulting in process acidification due to accumulation of products from upstream primary fermenting microorganisms. As a consequence, disproportioning will remain incomplete, hydrogen will not be converted and thus lost, and the digested residue will still contain a considerable methane potential. This will result in deficient process performance and profitability as well as environmental impacts.

It is therefore of uppermost importance to avoid process perturbations by providing optimum conditions for the biocenosis. Both microbiological and technical factors are interdependently determining the efficiency of the overall biotechnological AD process. Important items and new developments from both fields are discussed in the following.

\section{Microbiology and process control}

Microbial nutrition Sufficient nutrients with suitable macro- and trace element (TE) composition must be provided along with other factors such as suitable water content and sufficient retention time to allow proliferation of even the most slowly growing process-relevant microbe. C/N/P/S ratios in the range of 300 to $600 / 15 /$ $5 / 1$ to 3 turned out to be a good clue [1]. However, due to inconsistent or conflicting research and practice reports, there is considerable debate on minimum $\mathrm{TE}$ concentrations and heavy metal toxicity levels. Considering that anions such as sulfide or phosphate can precipitate and diminish the availability of several essential TEs, the presence of obscuring levels of precipitates and respectively altered TE bioavailability can explain inconsistent reports.

In order to define minimum levels of essential TEs, a long-term experiment was performed [30] feeding six mesophilic single-stage biogas fermenters only with maize silage, excluding noteworthy heavy metal precipitation by low sulfide and phosphate levels. By plotting process performance data against total concentrations of ICP-MS determined metal concentrations it turned out that Cobalt was the primarily limiting TE. At about $60 \mu \mathrm{g}$ Co per $\mathrm{kg}$ fresh matter (FM) first and at about $30 \mu \mathrm{g} \mathrm{Co} \cdot \mathrm{kg}_{\mathrm{FM}}{ }^{-1}$, severe acidosis symptoms with process breakdown were seen [30,31]. Cart analysis (http://www.statmethods. net/advstats/cart.html) revealed that Co deficiency was responsible at this experimental stage. After feeding stop, adjustment of TE concentrations, process recovery and re-continued operation, secondary acidosis and process breakdown due to sodium deficiency occurred. To our knowledge, this was the first report [31] that the AD process collapses due to Na deficiency, with a threshold at ca. $10 \mathrm{mg} \cdot \mathrm{kg}_{\mathrm{FM}}{ }^{-1} \cdot \mathrm{Na}^{+}$plays an essential role in energy conservation particularly of methanogens and syntrophic bacteria involved in the hydrogenotrophic pathway of methanogenesis [32,33], and hydrogenotrophic methanogens were dominant in the period before and at $\mathrm{Na}^{+}$deficiency. In support of the conclusions, metal/micronutrient determination of the fed maize silage batches (Table 1) confirmed correspondingly low concentrations of Co and of $\mathrm{Na}$ in the batches fed before and at the secondary acidification. $\mathrm{Ni}, \mathrm{Se}, \mathrm{Mo}$, and $\mathrm{Fe}$ concentrations were sufficiently provided by the maize silage in average, and threshold concentrations [31] were not reached in the fermenter sludges. However, synergistic detrimental effects on the biocenosis cannot be excluded if several TEs are concomitantly approaching limiting levels. TE threshold levels may also be increased if additional stressors such as $\mathrm{NH}_{3}$ are impeding the activity of the microbes.

Similarly low levels of Co $\left(40 \mu \mathrm{g} \cdot \mathrm{kg}_{\mathrm{FM}}{ }^{-1}\right.$ and less $)$ and $\mathrm{Na}\left(30 \mathrm{mg} \cdot \mathrm{kg}_{\mathrm{FM}}{ }^{-1}\right)$ were measured in rye silage, and rye silage-fed fermenters operated elsewhere acidified [35]. This indicates that AD of some cereals can cause problems, particularly if silages are of poor quality or leached, e.g., by rain. In such cases, necessary supplementation of specific TEs should be calculated by mass balances considering silage TE contents and fermenter sludge volume changes in order to avoid process acidification. However, adding more than required for optimum process performance $[21,31]$ typically does not lead to further improvement and should be avoided because toxicity problems can arise. Improvement by higher dosage points to additional limitations or TE precipitation, and efforts should be made in this case to increase the bioavailability by withdrawal of precipitating anions or agents.

Practice observation leads to the reminder that some TE compounds such as nickel, selenium, and cobalt salts are (extremely) toxic and should not be stored and used at the plant in unformulated or undiluted form. A market for process supplements has meanwhile established, but ingredients and recommended specific concentrations are not always made clear. More transparency on that field is urgently required to avoid abuse and eventual intoxication of staff and environment.

A reasonable and sustainable alternative to the addition of TE supplements can be the balanced addition of manure or grass silage if these resources are easily available. Grass silage typically has much higher contents of almost all TEs than maize silage (Table 1) and may thus be used to compensate TE deficits. It should be considered, however, that grass silage has also higher protein content (Table 2), 
Table 1 Typical composition of micronutrients in maize and grass silage from Bavaria (Germany)

\begin{tabular}{|c|c|c|c|c|c|c|c|c|c|c|}
\hline & Co & $\mathrm{Cu}$ & $\mathrm{Fe}$ & $\mathrm{Mn}$ & Mo & $\mathrm{Na}$ & $\mathrm{Ni}$ & Se & W & $\mathrm{Zn}$ \\
\hline Maize silage mean value $(n=16)$ & 0.026 & 1.83 & 22.8 & 4.35 & 0.18 & 16.6 & 0.15 & 0.01 & 0.007 & 5.95 \\
\hline Min to max & 0.004 to 0.11 & 1.20 to 2.90 & 8.09 to 40.4 & 1.66 to 11.2 & 0.030 to 0.31 & 2.73 to 30.5 & 0.04 to 0.39 & 0.003 to 0.018 & 0.003 to 0.01 & 1.66 to 10.8 \\
\hline Grass silage mean value $(n=16)$ & 0.14 & 3.27 & 354 & 37.7 & 1.54 & 145.8 & 0.98 & 0.08 & 0.18 & 15.9 \\
\hline Min to max & 0.038 to 0.59 & 1.80 to 4.56 & 39.1 to 1,919 & 6.80 to 157 & 0.25 to 2.57 & 66.4 to 295 & 0.09 to 2.55 & 0.01 to 0.26 & 0.05 to 0.43 & 9.05 to 35.9 \\
\hline
\end{tabular}

Data in $\mathrm{mg} \cdot \mathrm{kg}_{\mathrm{FM}}{ }^{-1}$; values in italics are alarming with respect to levels reported in [21,31]; data are compiled from $[30,31,34]$ and unpublished results. 
Table 2 Typical composition of maize and grass silage in Bavaria (Germany)

\begin{tabular}{|c|c|c|c|c|c|c|c|c|c|}
\hline & Raw protein & Raw fibers & Raw lipids & Cellulose & Hemicellulose & Lignin & Total C & Total N & $\mathrm{C} / \mathrm{N}$ ratio \\
\hline $\begin{array}{l}\text { Maize silage mean } \\
\text { value }(n=98)\end{array}$ & 7.4 & 21.3 & 2.4 & 23.5 & 26.1 & 3.6 & 46.2 & 1.2 & 38.7 \\
\hline Min to $\max$ & 5.7 to 10.4 & 16.4 to 39.0 & 1.1 to 3.7 & 19.0 to 39.9 & 14.5 to 35.6 & 1.6 to 7.0 & 41.3 to 47.1 & 0.1 to 1.7 & 26.5 to 51.5 \\
\hline $\begin{array}{l}\text { Grass silage mean } \\
\text { value }(n=78)\end{array}$ & 14.1 & 26.8 & 3.1 & 31.7 & 20.3 & 6.3 & 44.8 & 2.3 & 20.8 \\
\hline Min to max & 7.1 to 21.1 & 17.9 to 38.5 & 1.6 to 4.7 & 19.6 to 42.3 & 6.6 to 34.1 & 2.1 to 12.8 & 37.0 to 47.8 & 1.1 to 3.4 & 13.2 to 40.5 \\
\hline
\end{tabular}

Data in percentage (\%) of dry matter; data in italics indicate significant differences; data adopted from [34].

possibly giving rise to ammonia toxicity especially at higher process temperatures (see 'Process chemical conditions redox potential, buffer capacity, and toxic compounds' section).

Process chemical conditions - redox potential, buffer capacity, and toxic compounds The redox potential must be low enough (less than $-250 \mathrm{mV}$ ) to force the biocenosis towards carbonate respiration. If excess alternative electron (reduction equivalent) acceptors such as oxygen, sulfate, or nitrate are present, which would allow higher energy gain, carbonate respiration and thus methane formation is decreased. It was believed that e.g. sulfate reducing bacteria (SRB) cannot proliferate and are diluted out in flow-through systems if conditions do not allow for sulfate reduction. However, some SRB appear to have adopted a facultative syntrophic lifestyle in the absence of sulfate [33], degrading e.g. propionic acid with methanogenic Archaea, whereas some erstwhile SRB appear to have lost the ability to reduce sulfate [36]. This indicates that adaptation upon selection pressure and niche occupation is an ongoing mechanism also in biogas microbiology and may be exploited in respective biotechnological developments.

Enough carbonate buffer capacity in the fermenter sludge is important to stabilize the $\mathrm{pH}$ value in the neutral range, allowing for degradation of massively produced acids by fermenting bacteria after feeding with easily degradable organic matter. Buffer capacity problems are typically not observed with manure-based digestion systems. However, manure is not always available for biogas plants operated with energy crops. In a recent experiment, total inorganic carbon (TIC) drastically decreased from initially about $10 \mathrm{~g} \cdot \mathrm{L}^{-1}$ to less than $1 \mathrm{~g} \cdot \mathrm{L}^{-1}$ during 1.5 years of fermenter operation solely with maize silage, probably aggravating the detrimental effects of Co deficiency on the syntrophic methanogenic community [30,31] (see 'Microbial nutrition' section). Interestingly, TIC recovered soon after feeding stop. The successive development indicates that decreased TIC is a symptom and not the primary reason of process deficiency: TIC was still at about $5 \mathrm{~g} \cdot \mathrm{L}^{-1}$ at process breakdown due to $\mathrm{Na}$ deficiency (ca. $5 \mathrm{mg} \cdot \mathrm{L}^{-1}$ ) which had caused accumulation e.g. of iso-valeric acid up to
$1.8 \mathrm{~g} \cdot \mathrm{L}^{-1}$ and raised the ratio of 'total volatile acids' (TVA) to TIC to the extremely high level of nearly four [30,31] (see 'Microbial nutrition' section). The TVA/TIC ratio is widely used in practice as early warning parameter of process acidification. Such systems are discussed in the 'Microbial bioindicators and early warning systems' section.

There are reports that the introduction of some antibiotics [37], detergents, or heavy metals (e.g., excess copper and zinc used in animal husbandry $[38,39]$ ) of some metabolites produced internally in the AD process such as ammonia and phenolics, e.g. [40], and possibly of some mycotoxins present in silages can inhibit biogas production. However, practice and research reports are partially conflicting or even contradictory, and there are clues that the microbial biocenosis can adapt to some injurious compounds at least to certain extent [41]. Specific case studies under defined conditions including studies on the microbial populations are obviously necessary to work out dose-response relations and reveal reaction mechanisms. For experience with a broad range of organic and inorganic process inhibitors, the reader is referred to a review by Ye Chen and co-authors [42].

Ammonia inhibition due to an increased portion of proteinaceous compounds in the substrate mix narrowing the $\mathrm{C} / \mathrm{N}$ ratio (cf. 'Microbial nutrition' section) has been a matter of intense research particularly in biowaste digestion $[2,41,42]$. Research on ammonia inhibition was revived in $\mathrm{AD}$ of energy crops, with the increased utilization of (clover) grass silage for biogas production due to reduced dairy farming (cf. 'Agro-environmental and social aspects' section). Table 2 shows that besides considerable variation of data, total nitrogen in grass silage is typically the double of that in maize silage, which can cause inhibition of the $\mathrm{AD}$ process due to higher ammonia production. Higher contents of structural components are a challenge for feeding, pumping, and stirring devices (see 'Process engineering' section), in addition to ca. $5 \%$ higher ash content due to sand and stones from grass harvesting.

Ammonia problems at smaller $\mathrm{C} / \mathrm{N}$ ratios in the process are aggravating at increased process temperature. The buffer range is shifted into the mild alkaline range, and both, increased temperature and increased $\mathrm{pH}$ value, cause transition of ammonium to the toxic-free ammonia. Long-term mono digestion of grass silage was therefore 
only possible up to an organic loading rate (OLR) of $1.5-\mathrm{kg}$ volatile solids per $\mathrm{m}^{3}$ fermenter sludge (fs) and day $\left(\mathrm{VS} \cdot\left(\mathrm{m}_{\mathrm{fs}}^{3} \cdot \text { day }\right)^{-1}\right)$ at $55^{\circ} \mathrm{C}$, whereas at $38^{\circ} \mathrm{C}$, an OLR of $2.5 \mathrm{~kg} \mathrm{VS} \cdot\left(\mathrm{m}_{\mathrm{fs}}^{3} \cdot \text { day }\right)^{-1}$ was achieved [34]. Process disturbance with grass silage is typically observed above 400- to 500-mg-free $\mathrm{NH}_{3}-\mathrm{N}$ (FAN) per $\mathrm{L}_{\mathrm{fs}}^{-1}$. Since stable biogas process operation at higher FAN was reported with other substrates [2,41-43] other factors or compounds introduced with grass silage or produced during its digestion may contribute to toxicity [40]. There are hints in the cited literature and from practice that additives such as $\mathrm{Na}^{+}$and (activated) clinoptilolite can alleviate toxicity in $\mathrm{AD}$ of grass silage at least temporarily.

A major obstacle for early warning of process failure at high FAN is that the additional ammonium/ammonia buffer covers up acidification. Obtaining low TVA/TIC values although distinct TVA may already be at alarming level (but were not measured) can thus be misleading. Moreover, FAN can unspecifically inhibit microorganisms that carry out different process steps. Although methanogenesis is typically affected first, inhibition of hydrolysis/acidogenesis has also been observed (Andrade and Lebuhn, unpublished results): VFA and TVA/TIC were at low level, suggesting stable operation, but (organic) dry matter accumulated. These phenomena challenge the current process monitoring practice and suggest determining specific microbial activities during important turnover steps, using new molecular biology developments. Moreover, the selection of suitable adapted microbial biogas biocenoses deserves intensified studies. For these special microbiology tasks, the reader is referred to the 'Microbial bioindicators and early warning systems' section.

Thermodynamics and syntrophy, water content and agitation Thermodynamic laws require that reaction products, including intermediates, must be further converted or removed to avoid process feedback inhibition. The major biogas components $\mathrm{CH}_{4}$ and $\mathrm{CO}_{2}$ (and unavoidable gaseous by-products such as $\mathrm{NH}_{3}, \mathrm{H}_{2} \mathrm{~S}$, and $\mathrm{H}_{2} \mathrm{O}$ ) are withdrawn by gas utilization. Accumulation of organic matter and of incompletely oxidized compounds such as fatty acids or alcohols in the fermenter sludge, or of $\mathrm{H}_{2}$ in the gas phase, indicate a problem with the respective downstream converting step. $\mathrm{H}_{2}$ and formate are of outstanding importance in electron transfer between syntrophic donor bacteria and the accepting methanogens $[32,33,44,45]$. Along with syntrophic oxidation of other process intermediates, syntrophic acetate oxidation (SAO) was shown by results of different approaches to prevail in high throughput biogas processes, high-performance biogas plants particularly at high temperature and at high ammonia concentration [46-52]. The predominance of SAO in these processes is in contradiction to various textbooks assigning $70 \%$ of the methane to be produced by acetate splitting and only $30 \%$ via the hydrogenotrophic pathway.

Interspecies transfer of reduction equivalents between the syntrophic bacterial and methanogenic Archaea partners requires their close vicinity to avoid loss of hydrogen and respective reducing power, which is required for hydrogenotrophic methane formation, to the gas phase [44]. Acetate and other soluble intermediates may more or less freely diffuse in the liquid phase of the fermenter sludge up to a certain viscosity. However, their availability can become limited if stirring and pumping devices are working insufficiently. In conventional continuously stirred tank reactors, insufficient substrate degradation and process instability can thus be observed at dry matter contents above ca. $15 \%$. Propeller-type agitation devices operating with a high number of revolutions might disrupt the syntrophic associations and thereby decrease process efficiency. The challenge is to agitate just enough to achieve effective mixing of digester contents and release of biogas but not to disturb syntrophic associations by high shear force. Other technologies such as plug-flow systems (cf. 'Process engineering' section) can deal with higher dry matter contents and OLRs.

\section{Changing process conditions and microbial community} structure Significant and rapid changes in substrate composition and particularly of the process temperature should be avoided since the microbial population structure is self-optimizing to the given conditions and environment. Changing these will result in inactivation or decay of non-adapted community members. Considerable time with decreased process performance will pass until adapted substitute microbes will have grown to sufficient density and exert the desired activity. This adaptation process can result in important economical losses, as it can last 2 to 3 weeks, provided that there are no further interfering changes or stressors. In the following, microbial community structures and dynamics are shown and discussed. It is to be noticed that only biocenoses of single-stage reactors, i.e. of a monophasic biogas process are considered. Other processes such as biphasic systems [47] are not within the scope of this review.

Only methanogenic Archaea can produce considerable amounts of methane, and only these organisms carry coenzyme-B sulfoethylthiotransferase (EC 2.8.4.1, also known as methyl-coenzyme $M$ reductase), the key enzyme of methanogenesis. MCR, one of the two isofunctional enzymes, is encoded by $m c r$, and MRT, encoded by $m r t$, is additionally present in many Methanobacteria and Methanococci [53]. Certain Methanobacteria such as members of Methanosphaera and seemingly of an undescribed genus of the Methanobacteriaceae (see below) carry only mrt. As shown for Methanothermobacter thermoautotrophicus, $m o r$ and $m r t$ can be differentially transcribed 
depending on the growth conditions in syntrophic association or in pure culture [54].

The gene subunit $m c r \mathrm{~A} / m r t \mathrm{~A}$ presents several advantages as target for PCR-based analyses. Besides the functional specificity for methanogenesis, it can be used to infer phylogeny, as the topologies of $m c r \mathrm{~A} / m r t \mathrm{~A}$ and ribosomal DNA phylogenetic trees are almost identical [55], and resolution to the species level is possible. Moreover, transcription analysis involving RNA isolation and reverse transcription (RT) allows to detect the short-lived messenger RNA (mRNA) which is exclusively produced by active organisms. The mRNA approach avoids the potential bias that is associated with the detection of DNA or ribosomal RNA (rRNA): DNA and rRNA are relatively stable $[56,57]$ as compared with the short half-life of mRNA. Since the mRNA half-life median amounts to only few minutes and appears to be quite similar in bacteria and archaea [58], mRNA is ideally suited to trace guilds of viable organisms. DNA and rRNA, however, can originate from dormant organisms or be measurable as residues from dead cells or attached to surfaces for months.

Figure 1 shows the composition of the methanogenic biocenoses, as determined by $m c r \mathrm{~A} / m r t \mathrm{~A}$ amplicon cloning and sequence analysis, of continuously stirred tank reactors (CSTRs) efficiently digesting maize or grass silage at equilibrated mesophilic or thermophilic conditions. Members of the family Methanobacteriaceae (strictly hydrogenotrophic) and of the genus Methanosarcina (mixotrophic, hydrogenotrophic, and acetoclastic) dominated or were present at considerable concentration in all of the four experimental systems at the DNA level. Very few Methanosaeta sequences were found only in the mesophilic maize digesters. Acetate splitting and members of this strictly acetoclastic genus are typically found at low acetate and $\mathrm{NH}_{3}$ concentration and high microbial retention time [31,50-52,59]. Methanococci and Methanopyri, typically thriving in very hot environments, and anaerobic methane oxidizers were not recovered. However, a clade of sequences lacking any described taxon and branching off at the class or order level was identified (UC-II in Figure 1, sequences not only found in maize digestion) to which accordingly the status of a novel class or order should be given. UC-II represents one of the two subclades of the MCR-2 branch [60], more specifically MCR-2b [61]. For the second MCR-2 subclade (hitherto termed UC-I [31] or MCR-2a [61]),

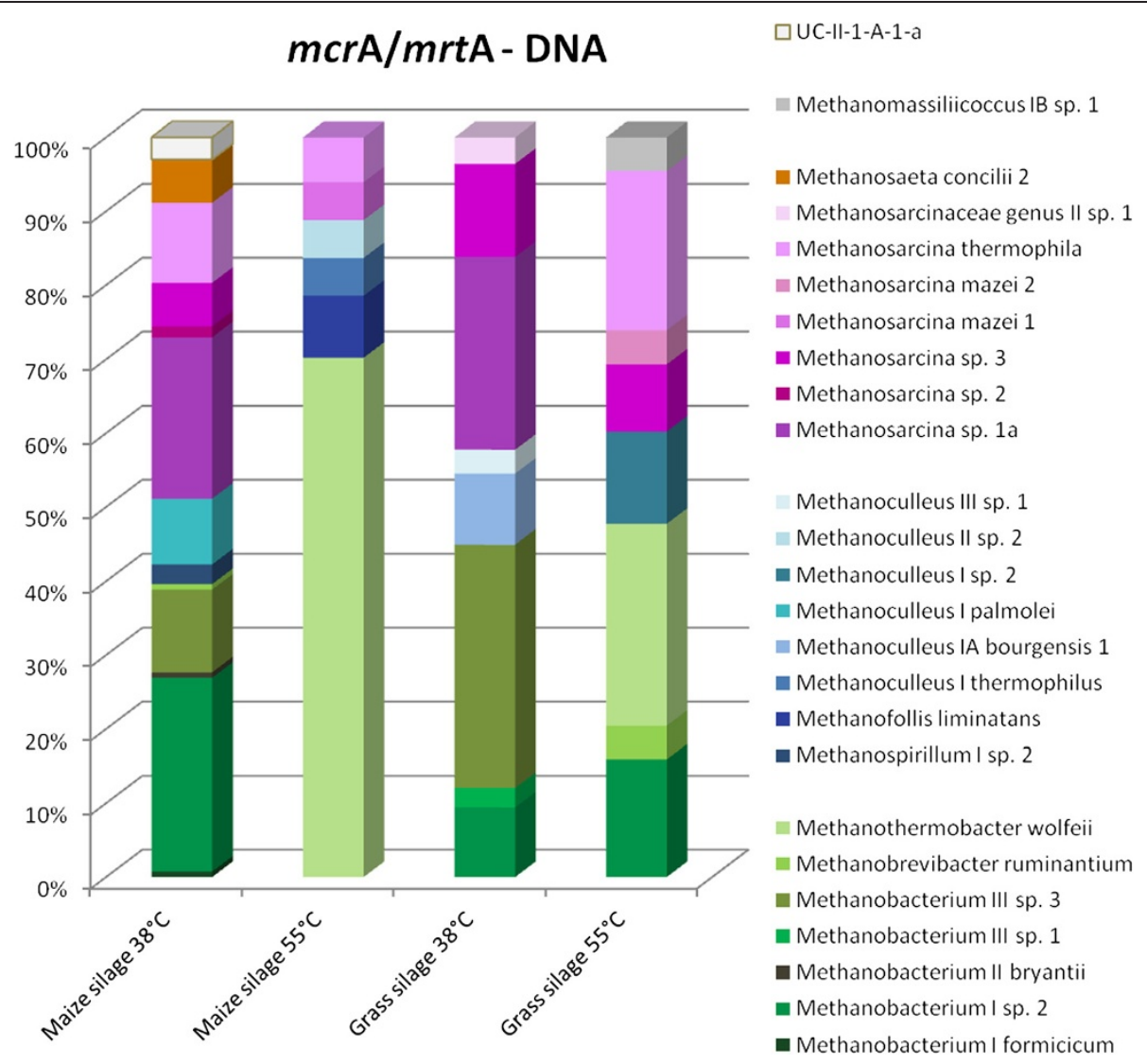

Figure 1 Composition of methanogenic biocenoses. The $m c r A / m r t A$ gene was determined in mesophilic $\left(38^{\circ} \mathrm{C}, \mathrm{m}\right)$ and thermophilic $\left(55^{\circ} \mathrm{C}, \mathrm{t}\right)$ digesters operated with maize $(M)$ or grass silage $(G)$; data from $[31,43]$ and from this work; sequences for $m M, m G$, $t M$, and tG are deposited at NCBI under accession numbers KJ487638 to KJ487705 (mM), KJ487559 to KJ487637 (mG), KJ487727 to KJ487741 (tM), and KJ487706 to KJ487726 (tG). 
the name 'Methanomassiliicoccales' or Mx order was recently proposed upon the description of some cultivated strains of this seventh order of methanogens [62].

Besides these higher-order similarities, the composition of methanogens was considerably different between the four variants (Figure 1, presenting genospecies, operational phylogenetic entities delineated at ca. $2.5 \%$ amino acid sequence divergence). Methanothermobacter wolfeii representatives were only found in the CSTRs run at $55^{\circ} \mathrm{C}$ and were dominant or highly abundant at this temperature in both, the maize and the grass silage digesters, whereas Methanobacterium III sp. 3 and Methanosarcina sp. 1a were only found and dominant or highly abundant in the maize and the grass silage CSTRs run at $38^{\circ} \mathrm{C}$. In the mesophilic grass silage fermenters, a hitherto undescribed clade of sequences affiliating with Methanosarcinaceae (operationally named genus II) was identified (Figure 1). In acidified mesophilic maize-silage-fed fermenters, sequences affiliating with the hydrogenotrophic order Methanomicrobiales were abundant at the DNA level $[31,46]$, most probably due to their stability in acidic environments, but they are not necessarily the most active at such conditions (see below). Another novel clade falling into the mrtA branch of Methanobacteriaceae, operationally named Methanobacteriaceae II genus IV, was also frequently present at process acidosis of mesophilic maize digestion [63]. Other studies on mesophilic codigestion production-scale biogas plants fed with different substrates also reported that hydrogenotrophic methanogens were dominating among the Archaea at DNA level, but in these Methanoculleus representatives were most abundant $[64,65]$.

The results of the community analyses suggest that most phylogenetic lineages of methanogens do not contain cultivated and described strains, illustrating that our knowledge of these microorganisms and their activities is still very limited. However, identified sequence clades that were specific for certain process conditions can help to design process-specific molecular biomarkers in a microbial bioindicator concept (see 'Microbial bioindicators and early warning systems' section).

As touched above, high abundance of certain microorganisms at examined (typically disturbed) process conditions does not necessarily mean that these microbes are also highly active. The activity of methanogens can be assessed by analysis of $m c r \mathrm{~A} / m r t \mathrm{~A}$ transcripts, since it has been shown in several reports, e.g. [66,67], that mRNA transcribed from this gene (and measured as cDNA) correlates with methane production. Important differences between the composition of the total (DNA level) and the active (mRNA or cDNA level) population of methanogens were noticed, e.g. during mesophilic digestion of maize silage at disturbed process conditions: In Figure 2, the sludge of fermenter A showed strain at sampling date 1 and increased stress symptoms (higher MQ, see 'Microbial bioindicators and early warning systems' section) at date 2 but still excellent gas yield, whereas the sludge from fermenter B was acidified due to TE deficiency at date 1 and severely acidified at date 2 , and showed decreasing methane yield. Just as noted above, representatives of the order Methanomicrobiales increased from sampling date 1 to date 2 on the DNA level, whereas only mRNA of Methanobacterium species was found on the activity (cDNA) level (Figure 2). Similar differences between the communities on the mRNA and the DNA level were noticed recently by Nikolausz et al. [52]. These examples indicate that at disturbed, non-equilibrated process conditions, numerically predominant community members can become inactive whereas numerically minor populations can take over the major part of the job.

For proper interpretation of results from population structure analysis, it must be recalled that the traditional PCR cloning/sequencing approach brings along considerable uncertainty with samples containing high biological diversity. Anyway, a pre-condition for reliable results is that the used primers are specifically amplifying the targeted fraction of a gene or the respective products. Involving PCR (with suitable primers) means that results will be biased towards the more abundant sequences while underrepresented portions may be disregarded. Only a limited part of the actual diversity is amplified, although this might be the one that is functionally most important. Typically only a part of the amplicons is cloned and a randomly selected portion of the clones is sequenced. Thus, only the tip of the iceberg is analysed and considerable statistical uncertainty remains. If, e.g., a typical number of $10^{2} \mathrm{mcrA} / \mathrm{mrtA}$ clones from a fermenter sample is sequenced, this is representing only a fraction of about $10^{-6}$ of the $m c r A / m r t \mathrm{~A}$ sequences actually present in the same sample volume. The situation is further obscured by 'wobbling microdiversity', the fact that population structures can vary to a certain degree in comparable environments [68]. In spite of such uncertainty, astonishing agreement was obtained between population profiles from PCR cloning/sequencing and metagenome 454-pyrosequencing without involvement of a PCR-step [69]. The traditional PCR cloning/sequencing approach can apparently produce reliable results if the abovementioned pre-conditions are met.

Anyway, analysis of more data is expected to infer higher statistical certainty. Due to recent progress of pyrosequencing and other 'next-generation sequencing' techniques [70], the analysis of a considerably increased number of sequences is becoming affordable. This allows assessing a significantly broader spectrum of the actual diversity and confers higher statistical confidence of the results, irrespective of the integration or omission of potentially selective steps such as gene-targeted PCR. 


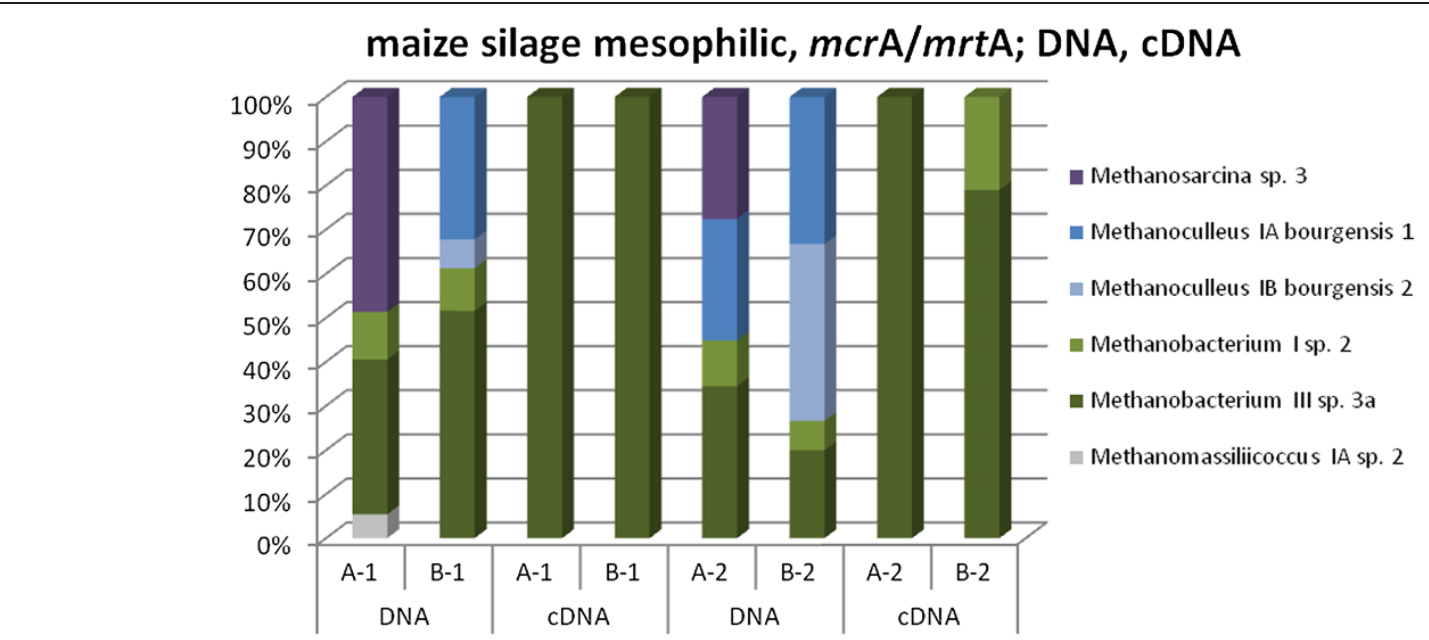

Figure 2 Composition of methanogenic biocenoses (A, B). The mcrA/mrtA gene (DNA) and transcripts (CDNA) were determined in mesophilic maize-fed digesters at two sampling dates (1, 2); sequences are deposited at NCBI under accession numbers KJ487742 to KJ487853.

Although more results on a solid statistical basis are clearly required, there is evidence from the hitherto obtained analyses that nutrient availability and changes in process conditions are affecting the composition of the present and active biocenosis. Changes of the active microbial community can in turn alter process conditions and performance. Once they are clearly identified, microbial process indicator taxa or genospecies, e.g., for acidification or ammonia toxicity, can be ideal tools for early warning of process perturbation. The bioindicator concept and other new molecular biology developments to predict the process performance are presented in the following 'Microbial bioindicators and early warning systems' section.

Microbial bioindicators and early warning systems As outlined below in the 'Process engineering' section, early warning of process perturbation is of major importance for economic and ecologically sustained operation of a biogas plant. However, in some cases, particularly with smaller and elder biogas plants, the only indicator of insufficient performance or process instability for the operator is his observation that the income did not meet his expectation. Nevertheless, the situation with respect to assessing and controlling the performance of biogas plants has considerably improved in the last years. Based on the monitoring of real-world biogas plants, benchmarks for state-of-the-art characteristic performance figures were established [19,71]. They can be used by plant operators to interpret their own process data and evaluate the possible need for optimization measures, e.g., also in online applications [72]. Important process data include chemical parameters in the digester content such as dry and organic dry matter (total solids, TS, and volatile solids, VS), shortchain fatty acids (SCFA, sometimes referred to as VFA, volatile fatty acids) the TVA/TIC ratio and $\mathrm{NH}_{4}^{+}-\mathrm{N}$ in conjunction with temperature and $\mathrm{pH}$, as outlined in 'Process chemical conditions - redox potential, buffer capacity, and toxic compounds' and 'Thermodynamics and syntrophy, water content and agitation' sections. Some of these parameters, e.g., TS, VS, and the TVA/TIC ratio, can easily be determined directly on site, whereas others such as SCFA or analysis of nucleic acids require the equipment and know-how of a specialized laboratory. For the latter, samples must be transported to the lab, and some parameters require special transport conditions. It is emphasized that representativeness of sampling is most crucial for the reliability of the result.

As outlined above, it is of paramount interest to keep the digestion process stable and identify imbalances that could lead to process instability as early as possible. However, chemical indicators are not always reliable for indicating process acidification. For example, the frequently used TVA/TIC ratio can be biased due to the high buffer capacity of the ammonium/ammonia system. It is recalled that indicator compounds and intermediates such as SCFA and ammonia are produced by microbial activity. Changes of microbial activity do occur thus earlier and are responsible for the respective changes of chemical process indicator concentrations. Based on this perception, two lines of early warning systems using molecular biology techniques have been developed and are being refined: (i) The concept of microbial bioindicators and (ii) ecophysiological parameters such as the 'Metabolic Quotient' (MQ) and the cDNA/DNA ratio.

\section{Microbial bioindicators}

The microbial bioindicator concept is built on the results hitherto obtained for the composition of the biocenoses and active populations at distinct process conditions, 
including different substrates, process temperatures, and the recognized process status (e.g., efficient, inhibited, acidified). For each of these process conditions, the typical microbial population structure and active key players are identified (e.g. Figures 1 and 2 for methanogenic Archaea), and the population structure of the given process is compared with the established microbial population structure and activity 'benchmarks'.

Given balanced nutrition, the parameters of major importance for the development of process performance are the dilution rate and the possible growth rate of the single microbial populations at the given conditions. The input or formation of inhibitory compounds has a negative impact on the ability of the present microbial populations to cope with process conditions. This can lead to their disappearance and breakdown of the respective reaction step(s). If not counteracted, the entire process can collapse. According to current understanding, the most susceptible steps are the final methanogenesis and the upstream syntrophically linked intermediary metabolism [73,74]. The primary focus was thus on developing monitoring tools for methanogenic Archaea and syntrophic bacteria and their activity [31,46,75-77]. Further developments will include refinements, alternatives [33], and systems for the primary fermenting microorganisms (see below).

In the current bioindicator concept for methanogenic Archaea, significant presence and activity of obligatory acetoclastic Archaea such as Methanosaeta concilii and/or Methanosarcinaceae in the acetate splitting state indicate low acetate and FAN concentration and a low dilution rate or high microbial retention time [50,59]. These obligatory or facultative acetoclastic methanogens are typically found in fermenters operating at very low OLR and in systems where the methanogenic consortia are retained, e.g., in immobilized biofilms, (granular) sludge beds or on carrier support particles [31,78], [unpublished results] with high microbial retention time. The slowly growing Methanosaeta Archaea are losing their competitive advantage and are washed out with increasing OLR, dilution rate, VFA and/or ammonia concentration in their environment. Their task is taken over by members of the family Methanosarcinaceae by metabolic switch to the hydrogenotrophic pathway of methanogenesis and/or syntrophic consortia of SAO oxidizing bacteria and hydrogenotrophic methanogens.

Methanosarcina has been entitled the "heavy duty methanogen' [79], but this appears to be valid only to a limited extent. Representatives of this genus typically prevailed or were at least abundant at efficient operation of CSTRs with maize and grass silage (Figure 1) and other substrates such as cattle manure and mixtures thereof (not shown) without stress symptoms. However, in many stress situations hitherto tested, Methanosarcina became a minor fraction or was not recovered at all on the DNA level, and showed reduced or no transcriptional activity [31,50-52]. In these cases, members of the hydrogenotrophic family Methanobacteriaceae raised their activity (see Figure 2 as an example of TE deficiencyinduced acidosis), indicating that syntrophic fatty acid oxidation was dominant over acetate cleavage in methane production. A recent metaproteome study came to very similar conclusions at the protein level [80]. Also at high ammonia levels, there are many lines of evidence confirming that strictly hydrogenotrophic Archaea with different syntrophic bacterial partners are the workhorse teams producing methane via the acetate oxidation pathway (SAO) at meso- and thermophilic conditions [48,81-83]. The most important reason for these strain- and stressinduced population shifts is probably that particularly Methanobacterium and Methanothermobacter archaea have higher growth rates than Methanosarcina representatives and are thus more capable of coping with the dilution rate under the influence of stress factors in flow-through processes.

A generalized view summarizing the information on activity dynamics of methanogens or physiological groups in response to stress conditions is presented in Figure 3. The strength or amount of the category is increasing from left to right. The indicated bioindicator groups are currently being subdivided in subgroups in order to follow better-defined entities more specifically, as outlined above (see 'Changing process conditions and microbial community structure' section). Quantification of such defined bioindicators is a central aspect in the following subsection 'Ecophysiological parameters - Metabolic Quotient, and cDNA/DNA ratio'.

Similar constructs are currently being identified or generated for secondary fermenters including syntrophic bacteria that are performing the intermediary metabolism, as well as for the guild of hydrolytic/acidogenic bacteria, the primary fermenters. A first inventory of Bacteria thriving in a hydrolytic/acidogenic fermenter digesting a lignocellulose-rich straw/hay diet and on their activity is being compiled from metagenomics, metaproteomics, and the bacterial rrs gene and its transcripts [69,84-86]. Since these are only first attempts to extend the bioindicator concept to functional genes of bacteria, the respective presentation would exceed the scope of this review.

\section{Ecophysiological parameters - Metabolic Quotient and CDNA/DNA ratio}

Once microbial bioindicators are defined, respective specific molecular systems for the quantification of nucleic acids are developed. There are several approaches that can be followed, such as Southern/Northern blotting, fluorescent in-situ hybridization and quantitative real-time PCR (qPCR), optionally including a reverse transcription (RT) step (RT-qPCR) to quantify RNA 


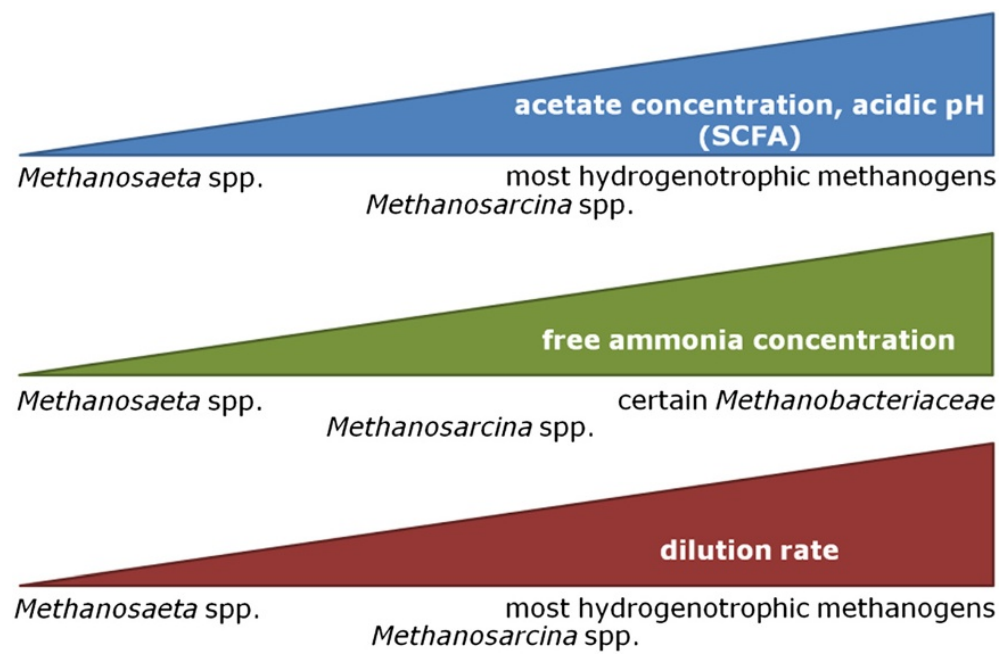

Figure 3 Activity dynamics of methanogens or methanogenic groups in response to stress conditions.

species such as messenger (mRNA) or ribosomal RNA (rRNA) which are transcribed to and measured as complementary DNA (cDNA). Among these, (RT-)qPCR has conquered the field due to its specificity, sensitivity, and suitability for high-throughput analysis $[87,88]$. Just as with many other analytical tools, the technique was first developed for medical applications, and was subsequently adopted by applied environmental sciences. Meanwhile (RT-)qPCR has become the 'gold standard' of gene and transcript quantification [89].

The reliability of (RT-)qPCR data is dependent on sample representativeness and homogeneity, nucleic acid extraction efficiency, and design and performance of the (RT-)qPCR system. All of these factors have a huge impact on the result, and different methods applied in different laboratories can be the source of considerable variation of results [89]. It is therefore essential to optimize sampling, sample processing and analysis, and to assess and report DNA and RNA recovery rates $[66,67]$ by quantifying the losses of the complete system, i.e., between the first sample preparation and the last analytical detection step, e.g., in a sample spiking approach. Results obtained with different methods cannot be compared if this information is not provided. For inter-laboratory comparison, optimized methods need to be standardized. Standardization was started with the last, the analytical step [90]. However, sample preparation and processing and particularly non-representative sampling are the most important sources of data variation.

Ecophysiological parameters will best be assessed by addressing physiological microbial groups, so-called guilds, performing well-defined metabolic steps in the investigated ecosystem. The guild of methanogenic Archaea is an excellent example of important microbial bioindicators since, exclusively, this physiological entity is carrying out methanogenesis. Activity of methanogenic Archaea is obligatory for methane production and can be addressed by physiological parameters such as (i) the methane productivity of a given fermenter sludge or (ii) transcription of the key enzyme of methanogenesis, and relating these to the concentration of methanogens in a given sludge volume. Although transcriptional activity is not necessarily correlated with the respective enzymatic activity, it can plausibly be assumed that in a functioning ecosystem 'trash transcription' will be selected out, leaving only the correctly functioning systems in the food chain.

In the first approach (i), the specific methanogenic activity (SMA) is determined and expressed as normalized (standard temperature, pressure, STP) methane volume produced per methanogenic cell and day. In long-term mesophilic digestion of maize silage at equilibrated conditions without signs of process disturbance, the concentration of methanogens followed a saturation curve in exponential correlation with the methane productivity, depending on the OLR (Figure 4) [67,91]. Figure 4 shows the reference dataset that has been refined from a matrix which is already devoid of data that had been obtained at acidified process states with TVA/TIC values $>0.7$ [31]. In order to compile a suitable reference dataset for the recently introduced 'Metabolic Quotient' (MQ, see below), further data, for which metabolic strain or stress (but at TVA/TIC $<0.7$ !) was assigned, were removed and transferred to the tester datasets. Similarly, data obtained at slack metabolism, at famine periods induced by interrupted feeding or at process recovery after acidosis, were removed. In the refined reference dataset, the standard SMAs $\left(\mathrm{SMA}_{\text {std }}\right)$ ranged between ca. 10 and $100 \mathrm{pL}_{\mathrm{STP}}$ $\mathrm{CH}_{4} \cdot$ methanogen $^{-1} \cdot$ day $^{-1}$. Actual SMAs $\left(\mathrm{SMA}_{\text {act }}\right)$ were lower at relaxed metabolism and famine process conditions, e.g., at reduced or without feeding, whereas higher $\mathrm{SMA}_{\text {act }}$ 


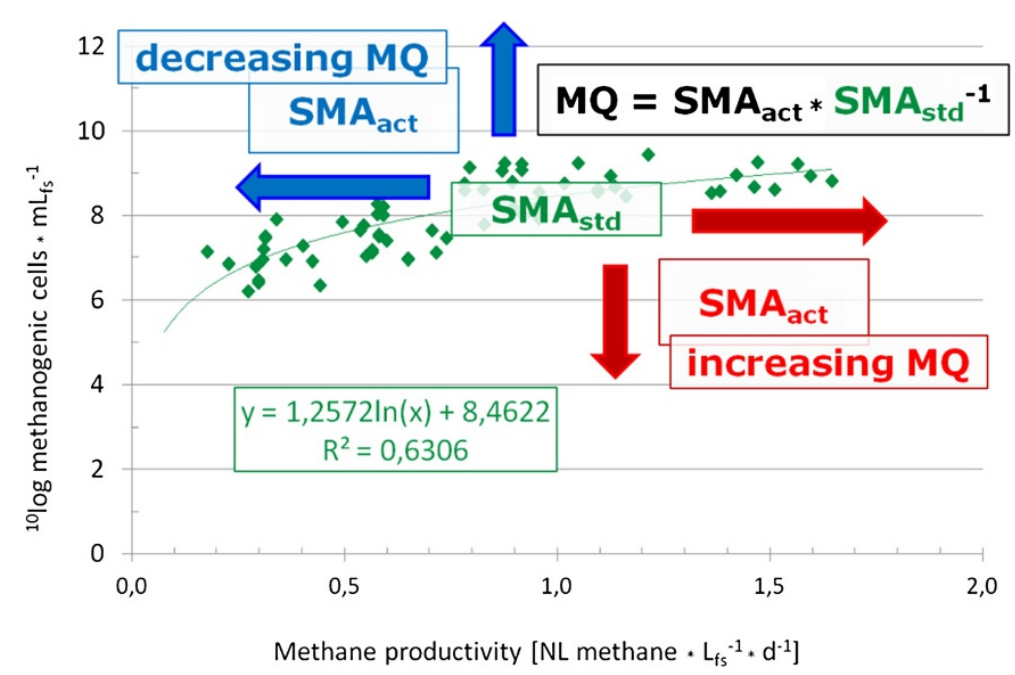

Figure 4 Correlation between concentration of methanogens and methane productivity in efficient anaerobic digestion of maize silage at $38^{\circ} \mathrm{C}$. Abbreviations are explained in the main text body.

were recorded at strained metabolism and much higher $\mathrm{SMA}_{\text {act }}$ at stress conditions induced e.g. by TE deficiency (cf. 'Microbial nutrition' section). $\mathrm{SMA}_{\mathrm{act}} \cdot \mathrm{SMA}_{\mathrm{std}}{ }^{-1}$ defines the MQ (Figure 4) [67,91]. In consideration of analytical and biological variation, MQ values between 0.1 and 3 are regarded normal. The MQ allows drawing conclusions with respect to the actual metabolic state of methanogens in the process, and the further development may be predicted by extrapolation of the recent development.

The MQ has been shown to be indicative of the fermenter status during mesophilic digestion of maize silage; an increase of MQ values to above 3 due to TE deficiency was observed already ca. 2 weeks before detectable changes of conventional chemical process indicators such as the TVA/TIC ratio or the concentrations of SCFAs $[63,67]$. This demonstrates the potential of this parameter as an early warning tool for process failure in practice. However, several questions still need to be answered. It must be assessed if the correlation shown in Figure 4 is also valid for other process conditions, e.g., at different temperatures or with different substrates. In case of deviations, respective specific calibrations must be initiated.

In the second approach (ii), the actual mRNA (or rRNA) concentration of specifically selected gene transcripts, measured as cDNA, is divided by the concentration of the corresponding gene, resulting in the cDNA/DNA ratio. It is important to normalize by the gene concentration present in the sample, since the transcript concentration is dependent on the transcriptional activity and the concentration of the microbes in question. This entirely molecular biological parameter is independent of gas analytical or process chemistry data which are not always available. It can be designed specifically for transcripts and genes coding for key enzymes of selected metabolic pathways or process steps such as $m c r \mathrm{~A} / m r t \mathrm{~A}$ for methanogenesis. Transcriptional activities of methanogens, expressed as $m c r \mathrm{~A} / m r t \mathrm{~A}$ cDNA/DNA ratios, have been reported for peat soil [66], flooded, and drained paddy field soil [92] and mesophilic maize silage-fed biogas processes at different levels of activity [63,67]. As expected, the $m c r \mathrm{~A} / m r t \mathrm{~A}$ cDNA/DNA ratios were correlated with methane production, indicating that assessing transcriptional activities can give valuable information on the activity of the targeted process step.

In the concept of microbial guilds, analytical systems are being developed also for certain bacterial groups that carry out the intermediary metabolism $[73,74]$. Some examples are fhs, encoding a key enzyme of the Wood-Ljungdahl pathway of autotrophic $\mathrm{CO}_{2}$ fixation [75-77] or hydA, encoding a Fe-Fe hydrogenase subunit which is central to the metabolism of $\mathrm{H}_{2}$ [93]. Other important steps include hydrolysis of lignocellulose biomass. Various enzymes of glycosyl-hydrolase families appear to be of major importance in this initial rate-limiting process. It is to be tested which of these genes and corresponding transcripts are best integrated into a diagnostic tool to determine the specific activity of the guilds constituting the process chain of anaerobic digestion and biogas production. This concept of physiological microbial guilds in the biogas process is currently being elaborated in order to provide a process diagnosis framework for application in practice.

\section{Process engineering}

In the real world, the variety of biogas installations with respect to capacity, design, technology, input materials, and utilization pathways is enormous. In Germany, as 
mentioned above, the rapid development of biogas production and utilization since the beginning of the 21st century was shaped by the Renewable Energy Act. Over the years, the framework of rules and technical guidelines for biogas systems became more specific and narrower. Since the biogas sector grew so rapidly, much of the technological development occurred 'on farm', not to say by 'trial-and-error'. One example is the devices for the feed-in of solid input materials. Basically, many of these were derived from systems for transportation and handling of animal feed. However, it turned out that the strain on these components within biogas installations, particularly due to abrasion, was much higher than anticipated by the suppliers, resulting in premature failures and considerable replacement cost $[94,95]$.

According to a survey in $2011 / 2012$, the majority of agricultural biogas systems in Germany featured two or more (dis-)continuously-stirred tank reactors in series [23]. Compared to a single reactor, this increases the mean retention time in the digester system. The digested residue is discharged into a storage tank. Forty-two percent of biogas installations surveyed had a covered storage tank with gas collection, avoiding methane emissions from digested residues during storage. By definition, a storage tank is neither heated nor stirred on a regular basis. Storage capacity has to be dimensioned according to regulations on organic fertilizer management and water protection.

The one-phase process design which can consist of several fermenters is thus the rule for agricultural biogas plants. Two-phase processes are designed to restrict, as far as practicability allows, hydrolysis/acidification phases and secondary fermentation/methanogenesis phases to separate reactors. The goal is to decrease the required retention time of the substrate, improve the control and thereby the efficiency of the overall digestion process, and produce methane-enriched biogas. At first glance, a twophase process appears to be an ideal concept to improve the hydrolysis of lignocellulose-rich material. However, recent results $[84,96]$ dampen expectations; acidic, as opposed to neutral $\mathrm{pH}$ value, appears to impede bacterial cellulolysis. Neutral $\mathrm{pH}$, however, favors methanogenesis, which is clearly undesirable in this pretreatment. It turned out that the retention time can considerably be reduced by the two-phase process, but this is at the expense of conversion efficiency and hydrogen losses.

In practice, a two-phase process can be difficult to realize with common agricultural inputs, and the number of such plants in agriculture is relatively small. However, a twophase process that is poorly operated and designed will not only be less efficient, but also bear the risks of uncontrolled methane and hydrogen emissions [97]. Further technological developments will identify suitable application areas, possibly in the context of bio-refinery concepts.
Basically, if mainly energy crops are utilized, comminution of the biomass occurs in the combine harvester. For input materials that might contain significant amounts of soil, such as sugar beets or grass, pre-treatment is advisable to avoid damage of machinery and sedimentation in the digester. While there are many options for additional pre-treatment of the input at the biogas plant, their economical viability should be examined in each individual case. In general, comminution or disaggregation of input materials with the aim of increasing degradation rate may be effective only if the hydraulic retention time in the digester system is comparably short, that is to say significantly below 80 days [98].

Although the technological standard of biogas plants has improved significantly over the last decade, the majority of biogas systems in agriculture is still behind industry standards in other branches, particularly with respect to plant safety, automation or quality control. One reason for this is that, at least for farm-scale installations with animal manure as main input, the construction costs constitute the major economical factor for the investor, i.e., the farmer. Therefore, except for 'large' installations (equivalent electrical output of more than $1 \mathrm{MW}$ ) connected to a biogas upgrading and feed-in facility, the level of process control and automation of biogas systems is at best intermediate but often low, still. Typically, full-range suppliers provide a process control system including visualization of the plant, logging of important process parameters and an alarm system for mobile phone. In simpler versions, no archiving of process parameters occurs, and the control systems for the digestion and co-generation units are separated. As far as the co-generation units are concerned, basically all of them are monitored remotely by the supplier. In 2012, it was prescribed that co-generation units are equipped with a remote control unit to enable the operator of the electricity network to reduce or interrupt electricity feed-in in cases of overload.

As described above, a number of chemical parameters are well known as meaningful indicators of the process status in most cases. As long as a biogas plant can be operated at modest loading rate and predominantly steady conditions with conventional substrates, it may be sufficient to check basic indicators such as TVA/TIC manually on a regular basis. This approach is quite inexpensive and in many cases sufficient to avoid major process failures (Figure 5). If signs of beginning destabilization appear, monitoring should be intensified, and more specific parameters such as characteristic SCFA and molecular microbiology analyses (see 'Changing process conditions and microbial community structure' and 'Microbial bioindicators and early warning systems' sections) may be included. Since these analyses require expensive instrumentation and skilled staff, they are 


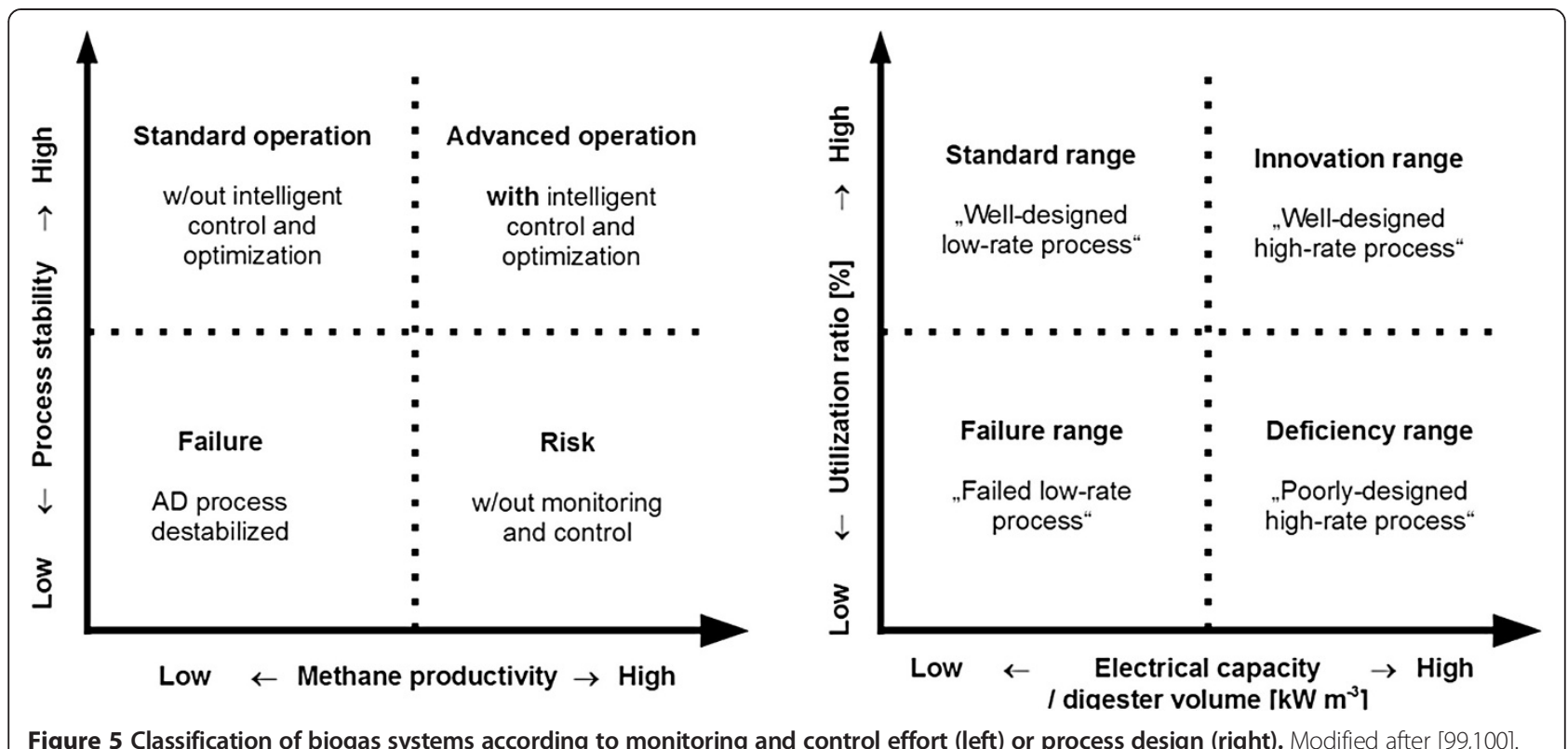

still restricted to offline determination by specialized laboratories, but this market is expected to grow.

In contrast, automatic monitoring and control of the anaerobic digestion process in full-scale biogas plants is complicated and costly. If the aim is to maximize the productivity of the digester system, or variations of the input and loading rate occur, process indicators will have to be measured in due time or at best online to preclude destabilization. The easiest but at the same time least meaningful measurements can be applied to the biogas stream. Better information can be drawn from analyzing the liquid phase; however, this can be more challenging in technical terms. Of particular interest is the detection of SCFA and dissolved hydrogen. While suitable sensors have been developed and tested at lab scale, these have not found their way into full-scale biogas installations so far [101]. A qualitative assessment of available onlinemeasurement equipment is given in Table 3 .
Of course, complete measuring equipment is not yet sufficient to provide automatic monitoring and control $(M \& C)$ of a biogas plant. The measuring data have to be integrated into a more or less advanced control system. Control systems that have been applied to AD processes include on/off, proportional-integral-derivative controller (PID), linearization, discontinuous control, complex control and expert systems, however, very seldom have they been tested at full scale [103]. As long as a biogas plant can be operated profitably in the 'standard range' as described in Figure 5, it will be difficult to convince the owner to install an advanced M\&C system, particularly in view of the fact that there are very few references in practice. In the future, with less favorable economic framework conditions and the demand for more flexible biogas production, $M \& C$ systems might become more established.

Currently, for a large share of small- and medium-sized biogas plants in agriculture, it would already be a clear

Table 3 Assessment of available online-measurement equipment for biogas plants

\begin{tabular}{|c|c|c|c|c|c|c|}
\hline & Unit & Effort & Maintenance & Robustness & Cost & Benefit \\
\hline Biogas composition & $\%(v / V)$ & + & -- & 0 & 0 & ++ \\
\hline Biogas rate & $m^{3} \cdot d^{-1}$ & 0 & 0 & ++ & + & + \\
\hline $\mathrm{pH}$ & & + & -- & - & - & 0 \\
\hline Redox potential & $\mathrm{mV}$ & + & -- & - & - & - \\
\hline TS content & $\%(m / m)$ & + & 0 & ++ & - & + \\
\hline VS content & $\%(m / m)$ & -- & -- & 0 & -- & ++ \\
\hline Temperature & ${ }^{\circ} \mathrm{C}$ & ++ & ++ & ++ & ++ & 0 \\
\hline SCFA content & $\mathrm{mg} \cdot \mathrm{L}^{-1}$ & -- & -- & ++ & -- & ++ \\
\hline Buffer capacity & $\mathrm{mg} \cdot \mathrm{L}^{-1}$ & -- & -- & ++ & -- & ++ \\
\hline
\end{tabular}

Rating: ++ very good; + good; 0 intermediate; - poor; - - very poor; TS, total solids; VS, volatile solids; SCFA, short-chain fatty acids; Modified and translated after [102]. 
step forward if owners did a basic performance assessment on a regular basis to derive possible optimization measures. By calculating a relatively small set of appropriate characteristic figures, the efficiency of biogas production and utilization systems can be described in quite a reliable and reproducible manner [104]. Also, using these characteristic figures, it is possible to set benchmarks for the state-of-the-art, and to compare and rank individual biogas plants [105]. The basic measuring equipment for determining the necessary performance figures includes at least the following: scale for all input materials; biogas analyzer and biogas flow meter in the supply pipe to the engine; electricity meters for the complete plant (plus for main individual consumers, possibly); operating hours counters for main components; heat meters for off-heat, digester heating and heat sales [106]. In addition, chemical analysis of input materials and digestate is required to evaluate digestion efficiency.

\section{Prospects and concepts}

With increasing implementation of wind and photovoltaic power plants, situations of surplus feed-in or overdemand of electricity are becoming more frequent. To balance supply and demand, efforts are being made in various technological fields to improve the storage of electricity, either directly or by way of converting electricity into energy carriers that are easier to store. One concept for the latter option is the physico-chemical conversion of $\mathrm{H}_{2}$ generated from electrolysis with $\mathrm{CO}_{2}$ (e.g., produced during $\mathrm{AD}$ ) to $\mathrm{CH}_{4}$ (so-called Sabatier process). However, this process is sensible to impurities, and has low conversion efficiency. Also, in the short and medium terms, the economical viability of such installations appears out of reach.

A promising alternative is microbial conversion, as hydrogenotrophic methanogenesis is a well-known and comparatively robust process (cf. 'Microbiology and process control' section) to convert $\mathrm{H}_{2}$ and $\mathrm{CO}_{2}$ to $\mathrm{CH}_{4}$. This type of methanation with an upstream electrolyzer can be realized by different concepts, e.g., by feeding $\mathrm{H}_{2}$ and $\mathrm{CO}_{2}$ to selected or enriched hydrogenotrophic methanogens in a separate methanogenic digester, or by feeding biogas and hydrogen to a biogas fermenter community in a separate reactor. In both ways, biogas with a methane content of $>90 \%$ could be produced at lab scale $[107,108]$. Ongoing experiments in pilot plants aim at evaluating the feasibility of such concepts in practice. Results will show if this type of hydrogenotrophic methanogenesis is a practicable and economic option to convert excess electricity into methane as a storable and versatile energy carrier. As an additional advantage, due to the already high methane content of the biogas, upgrading and feed-in of the gas into a gas grid, which possibly is already present, requires considerably less effort.
Process control will always be an important issue, and early warning systems of process failure are excellent options to take measures at diagnosed imbalances in due time. Molecular biology systems such as the MQ and the cDNA/DNA ratio (see 'Microbial bioindicators and early warning systems' section) have been developed and are at disposal for process monitoring in practice. Although online monitoring of these parameters currently appears to be infeasible, kit-based systems may be developed for use at the operators' premises. However, these will still require some basic laboratory equipment and may thus only be of value for larger plants. Portable PCR instruments for application in situ are already offered, and further miniaturization may allow the development of portable qPCR instruments. Besides eventual on-site application, custom analysis in a specialized laboratory is an option, but a long transport time is problematic if parameters involving the unstable messenger-RNA are to be analyzed. Preliminary sample preparation is required in such cases to fix the actual mRNA concentration on-site, waiving further mRNA turnover. The development of such kit-based systems appears realistic so that such kits may soon be found on the market.

From the perspective of agriculture, a biogas plant is supposed to generate profit for its owner(s) and added value for the region. However, to be regionally wellintegrated, the capacity of a biogas plant has to be compatible with the agricultural and ecological limitations of its surroundings [109]. If these limitations are ignored, this will have serious economical and environmental impacts, as it can be witnessed in those regions in Germany where high livestock densities have been combined with a large concentration of biogas plants. Such misguided developments are a threat to the public acceptance of biogas plants in general, which on the other hand is an important trigger for the future implementation of this industry, as outlined above.

From the perspective of electricity supply, biogas plants are flexible power stations that could make a significant contribution to the balancing of demand and supply within an energy system based on fluctuating renewable sources. However, this ability of biogas plants has hardly been exploited so far due to unsuitable regulations and economic framework conditions. Typically, to be eligible for the balancing power market, biogas plants will have to be bundled economically by a trader.

From the technical point of view, the plants have to be upgraded in such a way that biogas production and utilization can be decoupled over a certain period of time. In a first step, to balance electricity demand and photovoltaic supply curves, it makes sense to go from a 24-h operation of the generator to two 4-h intervals per day. Assuming no changes in the biogas production, this requires a new generator with about triple the output of 
the old one, combined with sufficient gas storage capacity. In addition, not to sacrifice the thermal utilization ratio, heat buffer storage capacity must be provided on site or at the purchasers' premises. For rural biogas plants in the lower capacity range, possibly fed mainly with animal manure, the economical viability of participating in the free market will likely remain out of reach. In these cases, a better solution might be the optimization of local energy supply for own and/or demand in close vicinity.

On this background, the challenge for the future appears to be the reconciliation of agro-environmental limitations and energy economics. By keeping this in mind and installing the necessary regulatory framework, it should be possible to exploit the beneficial potential of biogas as a versatile and renewable energy source. Given the respective economical incentives, there is large potential to significantly improve the productivity and stability of AD processes by building on the technological advances that have been summarized above with emphasis on optimization of every single step involved in biogas production and utilization.

\section{Conclusions}

This review shows that although agricultural biogas technology in Germany has been subject to quite a lot of scientific research and technological progress, there is still significant potential for optimization. At the same time, misguided trends should remind us of the fact that no technology is 'good in itself' but must be implemented within ecological, economical, and social boundary conditions. For the sustainable development of biogas technology in agriculture, we consider the following aspects most important:

- To improve the efficiency of existing biogas installations, tools for performance assessment and benchmarking of biogas plants are needed that have a solid methodological basis and are at the same time easy to use for the farmer. For this, basic measuring equipment for biogas plants is indispensable and should be disseminated much more.

- While monitoring and control $(M \& C)$ of $A D$ plants in practice should be improved significantly, the respective equipment needs to be tailored to the design and overall framework conditions of the individual biogas installation. The target level of methane productivity or better methane yield can be used as a first indicator of $M \& C$ requirements.

- Recent advances in the use of molecular biology tools have very much improved the understanding of the $\mathrm{AD}$ process and the function of microorganisms involved. Bioindicators and novel eco-physiological parameters such as the MQ and cDNA/DNA ratios are ideal supplements of the conventional chemical indicators for monitoring and controlling $\mathrm{AD}$ process stability at distinct process stages.

- These molecular biology tools have been developed as early-warning systems of process failure. They are excellent options to take measures at diagnosed imbalances in due time and preclude process breakdown. The analysis of bioindicators, the MQ and cDNA/DNA ratios still require a specialized laboratory, but further instrumental developments and miniaturization should allow for on-site analysis in the not-too-distant future.

- Given suitable economical and regulatory framework conditions, higher standards for biogas technology from the electricity supply system could foster the development and dissemination of innovative $M \& C$ technology that is currently not economically attractive.

- It seems debatable whether biogas plants in the lower capacity range can be integrated into the balancing power market or should rather be part of energy supply concepts on a local level.

- One of the most prominent factors for the sustainability of biogas production is the sustainable production or sourcing of the input materials. We see a substantial need for research into the environmental effects of agricultural production processes and for the development of suitable assessment methods.

- The integration of biogas plants into an energy supply network based on volatile renewable energies is a major challenge. For bigger plants, electricity and heat or gas supply on demand appear to be an excellent option to bridge production gaps of the volatile renewables. Using novel 'power-to-gas' technologies, surplus production of electricity may be transformed to 'biomethane' and stored in the gas grid.

Competing interests

The authors declare that they have no competing interests.

Authors' contributions

BM performed most and ML some of the molecular biological analyses. ME and $\mathrm{ML}$ compiled the data and wrote the paper, with the focus of ME on technology and ML on molecular microbiology sections. All authors read and approved the final manuscript.

\section{Acknowledgements}

We thank Elena Madge-Pimentel for excellent technical assistance. The authors' research work mentioned in this review were in large part funded by the Bavarian State Ministry for Nutrition, Agriculture and Forestry under grant numbers K/08/02, K/08/03, K/08/05, and K/08/06

\section{Author details}

${ }^{1}$ Bavarian State Research Center for Agriculture, Department for Quality Assurance and Analytics, Lange Point 6, 85354 Freising, Germany. ${ }^{2}$ Bavarian State Research Center for Agriculture, Institute for Agricultural Engineering and Animal Husbandry, Vöttinger Straße 36, 85354 Freising, Germany. 


\section{References}

1. Weiland P (2010) Biogas production: current state and perspectives. Appl Microbiol Biotechnol 85:849-860

2. Braun R, Drosg B, Bochmann G, Weiß S, Kirchmayr R (2010) Recent developments in bio-energy recovery through fermentation. In: Insam H et al (eds) Microbes at Work. Springer, Berlin Heidelberg, pp 35-58, 10.1007/ 978-3-642-04043-6_2

3. The University of Adelaide (2013) A brief history of biogas., http://www. adelaide.edu.au/biogas/history/, Accessed 2014-04-12 20:00 h

4. Weir A (2013) History of biogas technology., http://www.cd3wd.com/ cd3wd_40/BIOGSHTM/EN/BASICS/HISTORY.HTML, Accessed 2014-04-12 20:00 h

5. Kingdom Bioenergy Ltd (2013) History of biogas 1., http://www.kingdombio. com/history1.html, Accessed 2014-04-12 20:00 h

6. Fachverband der Gas- und Wärmeversorgungsunternehmungen (2013) Energieträger Biogas., http://www.gaswaerme.at/bbg, Accessed 2014-04-12 20:00 h

7. The Institute of Science in Society (2013) Biogas China., http://www.i-sis.org. uk/BiogasChina.php, Accessed 2014-04-12 20:00 h

8. Fachverband Biogas e.V (2013) Branchenzahlen - Prognose 2013/2014., http:// www.biogas.org/edcom/webfvb.nsf/id/DE_Branchenzahlen/\$file/13-1111_Biogas\%20Branchenzahlen_2013-2014.pdf, Accessed 2014-05-28

9. BMU (2010) Nationaler Aktionsplan für erneuerbare Energie., http://www. erneuerbare-energien.de/erneuerbare_energien/international/eu-richtlinie/ nationaler_aktionsplan/doc/46202.php, Accessed 2014-04-12 20:00 h

10. Arbeitsgruppe Erneuerbare Energien - Statistik (2013) Erneuerbare Energien in Zahlen, Stand Dezember 2013., http://www.erneuerbare-energien.de/ fileadmin/Daten_EE/Dokumente_PDFs_/ee_in_zahlen_bf.pdf, Accessed 2014-04-12 20:00 h

11. Federal Ministry for the Environment, Nature Conservation, Building and Nuclear Safety (2013) Development of renewable energy sources in Germany in 2012, last update: Dec. 2013., http://www.erneuerbare-energien. de/en/unser-service/mediathek/downloads/detailview/artikel/developmentof-renewable-energy-sources-in-germany-in-2011-graphics-and-tables/, Accessed 2014-04-12 20:00 h

12. Federal Ministry for the Environment, Nature Conservation, Building and Nuclear Safety (2011) Hintergrundinformationen zum Ausbau der Erneuerbaren Energien in Deutschland bis 2020., http://www.erneuerbareenergien.de/fileadmin/ee-import/files/pdfs/allgemein/application/pdf/ hintergrund_ausbau_ee_bf.pdf, Accessed 2014-04-12 20:00 h

13. Fachagentur Nachwachsende Rohstoffe (2011) Domestic bioenergy: Potential 2050., http://mediathek.fnr.de/catalog/product/gallery/id/494/ image/364/, last accessed 2014-04-12 20:00 h

14. European Union (2009) Regulation (EC) No 1069/2009 of the European Parliament and of the Council of 21 October 2009 laying down health rules as regards animal by-products and derived products not intended for human consumption and repealing Regulation (EC) No 1774/2002 (Animal by-products Regulation)., http://europa.eu/legislation_summaries/food_safety/animal_nutrition/sa0025_en.htm

15. Bundesministerium der Justiz zu Bonn (1998) BioAbfV, Verordnung über die Verwertung von Bioabfällen auf landwirtschaftlich, forstwirtschaftlich und gärtnerisch genutzten Böden (Bioabfallverordnung - BioAbfV - German regulation for biological waste), Bioabfallverordnung vom 21. September 1998 (BGBI. I S. 2955), zuletzt durch Art. 4 VO vom 23. April 2012 (BGBI. I S. 611, 659) geändert., http://www.gesetze-im-internet.de/bioabfv/

16. Schiermeier Q (2013) Germany's energy gamble. Nature 496(11):156-158

17. Schäfer R (2012) Möglichkeiten und Potenziale von erneuerbaren Energien in Bayern. LfL-Schriftenreihe 12:9-21, ISSN 1611-4159

18. Bayerische Landesanstalt für Landwirtschaft, Institut für Ländliche Strukturentwicklung, Betriebswirtschaft und Agrarinformatik (2011) Nutzung von Grünland zur Biogaserzeugung, Machbarkeitsstudie. LfL-Schriftenreihe 4:218, ISSN 1611-4159

19. Fachagentur Nachwachsende Rohstoffe (2013) Basisdaten Bioenergie Deutschland, August 2013., http://mediathek.fnr.de/media/downloadable/ files/samples/b/a/basisdaten_9x16_2013_web_neu2.pdf, Accessed 2014-0412 20:00 h

20. C.A.R.M.E.N (2014) Akzeptanz für Erneuerbare Energien, ein Leitfaden., http:// www.carmen-ev.de/files/Sonne_Wind_und_Co/Akzeptanz/ Akzeptanzbroschuere.pdf, Accessed 2014-04-12 20:00 h

21. Lebuhn M, Effenberger M (2012) Hygienisierung durch Biogastechnologie. Korrespondenz Wasserwirtschaft 8(12):419-424
22. Effenberger M, Bachmaier J, Garcés G, Gronauer A, Wilderer PA, Lebuhn M (2006) Mesophilic-thermophilic-mesophilic anaerobic digestion of liquid dairy cattle manure. Water Sci Tech 53(8):253-261

23. Rensberg N, Hennig C, Naumann K, Billig E, Sauter P, Daniel-Gromke J, Krautz A, Weiser C, Reinhold G, Graf T (2012) Monitoring zur Wirkung des Erneuerbare-Energien-Gesetz (EEG) auf die Entwicklung der Stromerzeugung aus Biomasse. In: Deutsches Biomasseforschungszentrum (DBFZ) (ed) Report to Projektträger Jülich GmbH. FZK, 03MAP138, Berlin, Leipzig

24. Vogt R, Gärnter S, Münch J, Reinhardt G, Köppen S, Daniel J, Postel J, Scholwin F, Klinski S, Brohmann B, Fritsche UR, Hennenberg K, Hünecke K, Rausch L, Köppel J, Peters W, Pusch E, Schultze C (2008) Optimierungen für einen nachhaltigen Ausbau der Biogaserzeugung und -nutzung in Deutschland. Project Report to the German Federal Ministry of Environment, Nature and Reactor Safety, FKZ, 0327544, Heidelberg, Leipzig, Berlin, Darmstadt

25. Bachmaier H, Effenberger M, Gronauer A, Boxberger J (2013) Changes in greenhouse gas balance and resource demand of biogas plants in southern Germany after a period of three years. Waste Manag Res 31(4):368-375

26. Bachmaier H (2012) Treibhausgasemissionen und fossiler Energieverbrauch landwirtschaftlicher Biogasanlagen - Eine Bewertung auf Basis von Messdaten mit Evaluierung der Ergebnisunsicherheit mittels Monte-Carlo-Simulation. Dissertation, Universität für Bodenkultur, Wien

27. Liebetrau J, Reinelt T, Clemens J, Hafermann C, Friehe J, Weiland P (2013) Analysis of greenhouse gas emissions from 10 biogas plants within the agricultural sector. Wat Sci Tech 67(6):1370-1379

28. Anonymous (2007) Nutzung von Biomasse zur Energiegewinnung Empfehlungen an die Politik / Use of biomass for energy generation - recommendations to policy makers. Wissenschaftlicher Beirat Agrarpolitik beim Bundesministerium für Ernährung, Landwirtschaft und Verbraucherschutz / Scientific Advisory Board on Agricultural Policy of the German Federal Ministry of Food and Agriculture, Berlin, http://www.bmel.de/SharedDocs/Downloads/Ministerium/Beiraete/Agrarpolitik/GutachtenWBA.pdf?_blob=publicationFile, Accessed 2014-04-14 13:00 h

29. Mclnerney MJ, Struchtemeyer CG, Sieber J, Mouttaki H, Stams AJM, Schink B, Rohlin L, Gunsalus RP (2008) Physiology, ecology, phylogeny, and genomics of microorganisms capable of syntrophic metabolism. Ann N Y Acad Sci 1125:58-72

30. Lebuhn M, Liu F, Heuwinkel H, Gronauer A (2008) Biogas production from mono-digestion of maize silage - long-term process stability and requirements. Water Sci Tech 58(8):1645-1651

31. Munk B, Bauer C, Gronauer A, Lebuhn M (2010) Population dynamics of methanogens during acidification of biogas fermenters fed with maize silage. Eng Life Sci 10(6):496-508, 10.1002/elsc.201000056

32. Thauer RK, Kaster AK, Seedorf H, Buckel W, Hedderich R (2008) Methanogenic archaea, ecologically relevant differences in energy conservation. Nat Rev Microbiol 6(8):579-591

33. Stams AJM, Plugge CM (2009) Electron transfer in syntrophic communities of anaerobic bacteria and archaea. Nat Rev Microbiol 7:568-577

34. Effenberger M, Andrade D, Bachmaier H, Lebuhn M, Marín-Peréz C, Spatz A (2011) Verfahrenstechnik der Grasvergärung: Technik, Gärprozess, Klimabilanz. In: Kongressband der 20. Jahrestagung des Fachverbands Biogas e.V., 11.1.-13.1.2011, Nürnberg, pp 29-37

35. Schattauer A, Abdoun E, Weiland P, Plöchl M, Heiermann M (2011) Abundance of trace elements in demonstration biogas plants. Biosyst Engin 108:57-65

36. Imachi H, Sekiguchi Y, Kamagata Y, Loy A, Qiu YL, Hugenholtz P, Kimura N, Wagner M, Ohashi A, Harada H (2006) Non-sulfate-reducing, syntrophic bacteria affiliated with Desulfotomaculum Cluster I are widely distributed in methanogenic environments. Appl Environ Microbiol 72(3):2080-2091

37. Mitchell SM, Ullman JL, Teel AL, Watts RJ, Frear C (2013) The effects of the antibiotics ampicillin, florfenicol, sulfamethazine, and tylosin on biogas production and their degradation efficiency during anaerobic digestion. Biores Tech 149:244-252

38. Karri S, Sierra-Alvarez R, Field JA (2006) Toxicity of copper to acetoclastic and hydrogenotrophic activities of methanogens and sulfate reducers in anaerobic sludge. Chemosphere 62(1):121-127

39. Sayder B, Vitz H, Mohring S, Merrettig-Bruns U, Kabasci S, Hamscher G, Türk J (2009) Gehemmte Biologie. Biogas Journal 02(09):44-45

40. Hecht C, Griehl C (2009) Investigations on the accumulation of aromatic compounds during biogas production from kitchen wastes. Biores Tech 100:654-658

41. Calli B, Mertoglu B, Inanc B, Yenigun O (2005) Effects of high free ammonia concentrations on the performances of anaerobic bioreactors. Proc Biochem 40:1285-1292 
42. Chen Y, Cheng JJ, Creamer KS (2008) Inhibition of anaerobic digestion process: a review. Biores Tech 99:4044-4064

43. Kovács E, Wirth R, Maróti G, Bagi Z, Rákhely G, Kovács KL (2013) Biogas production from protein-rich biomass: fed-batch anaerobic fermentation of casein and of pig blood and associated changes in microbial community composition. PloS One 8(10):18, e77265

44. Schink B (1997) Energetics of syntrophic cooperation in methanogenic degradation. Microbiol Mol Biol Rev 61(2):262-280

45. Dolfing J, Jiang B, Henstra AM, Stams AJM, Plugge CM (2008) Syntrophic growth on formate: a new microbial niche in anoxic environments. App Environ Microbiol 74(19):6126-6131

46. Bauer C, Korthals M, Gronauer A, Lebuhn M (2008) Methanogens in biogas production from renewable resources - a novel molecular population analysis approach. Water Sci Technol 58(7):1433-1439

47. Klocke M, Nettmann E, Bergmann I, Mundt K, Souidi K, Mumme J, Linke B (2008) Characterization of the methanogenic Archaea within two-phase biogas reactor systems operated with plant biomass. System Appl Microbiol 31(3):190-205

48. Schnürer A, Nordberg A (2008) Ammonia, a selective agent for methane production by syntrophic acetate oxidation at mesophilic temperature. Water Sci Technol 57:735-740

49. Zakrzewski M, Goesmann A, Jaenicke S, Jünemann S, Eikmeyer F, Szczepanowski R, Al-Soud AA, Sørensen S, Pühler A, Schlüter A (2011) Profiling of the metabolically active community from a production-scale biogas plant by means of high-throughput metatranscriptome sequencing. J Biotech 158:248-258

50. Lü F, Hao L, Guan D, Qi Y, Shao L, He P (2013) Synergetic stress of acids and ammonium on the shift in the methanogenic pathways during thermophilic anaerobic digestion of organics. Water Res 47(7):2297-2306

51. Ho DP, Jensen PD, Batstone DJ (2013) Methanosarcinaceae and acetateoxidizing pathways dominate in high-rate thermophilic anaerobic digestion of waste-activated sludge. Appl Environ Microbiol 79(20):6491-6500

52. Nikolausz M, Walter RF, Sträuber H, Liebetrau J, Schmidt T, Kleinsteuber S, Bratfisch F, Günther U, Richnow HH (2013) Evaluation of stable isotope fingerprinting techniques for the assessment of the predominant methanogenic pathways in anaerobic digesters. Appl Microbiol Biotechnol 97(5):2251-2262

53. Thauer R (1998) Biochemistry of methanogenesis: a tribute to Marjory Stephenson. Microbiol 144:2377-2406

54. Luo HW, Zhang H, Suzuki T, Hattori S, Kamagata Y (2002) Differential expression of methanogenesis genes of Methanothermobacter thermoautotrophicus (formerly Methanobacterium thermoautotrophicum) in pure culture and in cocultures with fatty acid-oxidizing syntrophs. Appl Environ Microbiol 68(3):1173-1179

55. Luton PE, Wayne JM, Sharp RJ, Riley PW (2002) The mcrA gene as an alternative to 165 rRNA in the phylogenetic analysis of methanogen populations in landfill. Microbiol 148(11):3521-3530

56. Widmer G, Orbacz EA, Tzipori S (1999) $\beta$-tubulin as a marker of Cryptosporidium parvum oocyst viability. Appl Environ Microbiol 65(4):1584-1588

57. McKillip JL, Jaykus LA, Drake M (1999) Nucleic acid persistence in heat-killed Escherichia coli 0157: H7 from contaminated skim milk. J Food Protect 62(8):839-844

58. Andersson AF, Lundgren $M$, Eriksson $S$, Rosenlund M, Bernander R, Nilsson $P$ (2006) Global analysis of mRNA stability in the archaeon Sulfolobus. Genome Biol 7(10):R99

59. Smith KS, Ingram-Smith C (2007) Methanosaeta, the forgotten methanogen? Trends Microbiol 15:150-155

60. Castro H, Ogram A, Reddy KR (2004) Phylogenetic characterization of methanogenic assemblages in eutrophic and oligotrophic areas of the Florida Everglades. Appl Environ Microbiol 70(11):6559-6568

61. Steinberg LM, Regan JM (2009) mcrA-targeted real-time quantitative PCR method to examine methanogen communities. Appl Environ Microbiol 75 (13):4435-4442

62. Borrel G, O'Toole PW, Harris HM, Peyret P, Brugère JF, Gribaldo S (2013) Phylogenomic data support a seventh order of methylotrophic methanogens and provide insights into the evolution of methanogenesis. Genome Biol Evol 5(10):1769-1780

63. Munk B, Lebuhn M (2014) Process diagnosis using methanogenic Archaea in maize-fed, trace element depleted fermenters. Anaerobe, in press

64. Kröber M, Bekel T, Diaz NN, Goesmann A, Jaenicke S, Krause L, Miller D, Runte KJ, Viehöver P, Pühler A, Schlüter A (2009) Phylogenetic characterization of a biogas plant microbial community integrating clone library 16S-rDNA sequences and metagenome sequence data obtained by 454-pyrosequencing. J Biotechnol 142(1):38-49

65. Sundberg C, Al-Soud WA, Larsson M, Alm E, Yekta SS, Svensson BH, Sørensen SJ, Karlsson A (2013) 454 pyrosequencing analyses of bacterial and archaeal richness in 21 full-scale biogas digesters. FEMS Microbiol Ecol 85(3):612-626

66. Freitag TE, Prosser II (2009) Correlation of methane production and functional gene transcriptional activity in a peat soil. Appl Environ Microbiol 75(21):6679-6687

67. Munk B, Bauer C, Gronauer A, Lebuhn M (2012) A Metabolic Quotient for methanogenic Archaea. Water Sci Technol 66(11):2311-2317, 10.2166/wst.2012.436

68. Curtis TP, Sloan WT (2004) Prokaryotic diversity and its limits: microbial community structure in nature and implications for microbial ecology. Curr Opin Microbiol 7:221-226

69. Lebuhn M, Hanreich A, Klocke M, Schlüter A, Bauer C, Marín Pérez C (2014) Towards molecular biomarkers for biogas production from lignocelluloserich substrates. Anaerobe in press

70. Metzker ML (2009) Sequencing technologies—the next generation. Nat Rev Genet 11(1):31-46

71. Effenberger M, Lebuhn M, FNR/KTBL (2011) In: FNR/KTBL (ed) Repowering von Biogasanlagen zur Steigerung der Prozesseffizienz. Biogas in der Landwirtschaft - Stand und Perspektiven, 20-21.9.2011, Göttingen, pp 268-280, ISBN ISBN 978-3-941583-56-6

72. Biogas Forum Bayern (2012) Betreiberleitfaden., http://www.biogas-forumbayern.de/online-anwendungen/betreiberleitfaden, Accessed 2014-04-12 20:00 h

73. Drake HL, Horn MA, Wüst PK (2009) Intermediary ecosystem metabolism as a main driver of methanogenesis in acidic wetland soil. Environ Microbiol Rep 1(5):307-318

74. McInerney MJ, Sieber J, Gunsalus RP (2009) Syntrophy in anaerobic global carbon cycles. Curr Opin Biotechnol 20(6):623-632, 10.1016/j. copbio.2009.10.001

75. Leaphart AB, Lovell CR (2001) Recovery and analysis of formyltetrahydrofolate synthetase gene sequences from natural populations of acetogenic bacteria. Appl Environ Microbiol 67(3):1392-1395

76. Fröschle B, Munk B, Bauer C, Gronauer A, Lebuhn M (2011) Targeting syntrophic bacterial populations in biogas production using the formyltetrahydrofolate synthetase gene. In: Proceedings of the International IWA-Symposium on Anaerobic Digestion of Solid Waste and Energy Crops, Vienna, Austria, p 5

77. Müller B, Sun L, Schnürer A (2013) First insights into the syntrophic acetateoxidizing bacteria - a genetic study. Microbiol Open 2(1):35-53, $10.1002 / \mathrm{mbo} 3.50$

78. McHugh S, Carton M, Mahony T, O'Flaherty V (2003) Methanogenic population structure in a variety of anaerobic bioreactors. FEMS Microbiol Lett 219(2):297-304

79. De Vrieze J, Hennebel T, Boon N, Verstraete W (2012) Methanosarcina: the rediscovered methanogen for heavy duty biomethanation. Biores Technol 112:1-9

80. Heyer R, Kohrs F, Benndorf D, Rapp E, Kausmann R, Heiermann M, Klocke M, Reichl U (2013) Metaproteome analysis of the microbial communities in agricultural biogas plants. New Biotechnol 30(6):614-622

81. Westerholm M, Müller B, Arthurson V, Schnürer A (2011) Changes in the acetogenic population in a mesophilic anaerobic digester in response to increasing ammonia concentration. Microb Environ 26(4):347-353

82. Westerholm M, Levén L, Schnürer A (2012) Bioaugmentation of syntrophic acetate-oxidizing culture in biogas reactors exposed to increasing levels of ammonia. Appl Environ Microbiol 78(21):7619-7625

83. Niu Q, Qiao W, Qiang H, Li YY (2013) Microbial community shifts and biogas conversion computation during steady, inhibited and recovered stages of thermophilic methane fermentation on chicken manure with a wide variation of ammonia. Biores Technol 146:223-233

84. Köllmeier T, Zverlov W, Schwarz WH (2012) Mikrobiologie der Hydrolyse von Pflanzenfasern in Biogasanlagen. Bornim Agrartechn Ber 79:99-113, ISSN 0947-7314

85. Hanreich A, Schimpf U, Zakrzewski M, Schlüter A, Benndorf D, Heyer R, Rapp E, Pühler A, Reichl U, Klocke M (2013) Metagenome and metaproteome analyses of microbial communities in mesophilic biogas-producing anaerobic batch fermentations indicate concerted plant carbohydrate degradation. System Appl Microbiol 36(5):330-338 
86. Bauer C, Marín Pérez C, Munk B, Lebuhn M (2012) Bakterielle Populationen in der Hydrolysephase der Vergärung einer Stroh- und Heumischung. Bornim Agrartechn Ber 79:87-98, ISSN 0947-7314

87. D'haene B, Vandesompele J, Hellemans J (2010) Accurate and objective copy number profiling using real-time quantitative PCR. Methods 50(4):262-270

88. Derveaux S, Vandesompele J, Hellemans J (2010) How to do successful gene expression analysis using real-time PCR. Methods 50(4):227-230

89. Nolan T, Hands RE, Bustin SA (2006) Quantification of mRNA using real-time RT-PCR. Nat Protoc 1:1559-1582

90. Bustin SA, Benes V, Garson JA, Hellemans J, Huggett J, Kubista M, Mueller R, Nolan T, Pfaffl MW, Shipley GL, Vandesompele J, Wittwer CT (2009) The MIQE guidelines: minimum information for publication of quantitative real-time PCR experiments. Clin Chem 55(4):611-622

91. Lebuhn M (2012) Molekularbiologische Quantifizierung - ein neues Messkonzept zur Bewertung des Prozessstatus von Biogasanlagen. In: Kongressband der 2. VDI-Konferenz 'Prozessmesstechnik an Biogasanlagen, Fulda, pp 85-97, ISBN 978-3-942980-99-9

92. Watanabe T, Kimura M, Asakaw S (2009) Distinct members of a stable methanogenic archaeal community transcribe mcrA genes under flooded and drained conditions in Japanese paddy field soil. Soil Biol Biochem 41(2):276-285

93. Tomazetto G, Oliveira VM (2013) Investigation of the FeFe-hydrogenase gene diversity combined with phylogenetic microbial community analysis of an anaerobic domestic sewage sludge. World J Microbiol Biotech: 1-12, doi:10.1007/s11274-013-1363-8

94. Lehner A, Effenberger M, Gronauer A (2010) Optimierung der Verfahrenstechnik landwirtschaftlicher Biogasanlagen. LfL Schriftenreihe 2/2010, Freising, ISSN 1611-4159

95. KTBL (2009) Schwachstellen an Biogasanlagen verstehen und vermeiden. KTBL-Heft 84, Darmstadt, ISBN 978-3-939371-81-6

96. Marín-Pérez C, Weber A (2012) Potential and limitations of a two-phase anaerobic digestion system for the degradation of lignocellulosic biomass by biological treatment. Bornim Agrartechn Ber 79:9-21, ISSN 0947-7314

97. Beck J, Effenberger M, Friedrich F, Kissel R, Marín-Peréz C (2010) Empfehlungen zu Verfahren der Hydrolyse in der Praxis. Biogas Forum Bayern, http://www.biogas-forum-bayern.de/publikationen/ Empfehlungen_zu_Verfahren_der_Hydrolyse_in_der_Praxis_2013.pdf, Accessed 2014-04-12 20:00 h

98. FNR (2009) Biogas-Messprogramm II - 61 Biogasanlagen im Vergleich. Fachagentur Nachwachsende Rohstoffe e.V. FNR, Gülzow, 978-3-9803927-8-5

99. Wolf C (2010) Biogas, die Energie der Zukunft - Trends und aktuelle Forschung. Umweltringvorlesung. 25.10.2011, Cologne University of Applied Sciences, http://www.f10.fh-koeln.de/imperia/md/content/mitteilungen/ umweltringvorlesung_25.11.2010_biogas_die_energie_der_zukunft trends_und_aktuelle_forschung.pdf, Accessed 2013-26-10 15:00

100. Effenberger M, Kissel R, Lehner A, Gronauer A (2008) Technical assessment of agricultural biogas plants - utilization ratio and energy efficiency. Landtechnik 63(5/2008):290-292

101. Junne S, Kielhorn E, Hörig A, Pässler A, Vonau W, Fenske M, Hälsig C, Neubauer P (2013) Überblick über Online-Messmethoden im Biogasprozess in Forschung und Praxis: Stand der Technik und Perspektiven. In: Biogas in der Landwirtschaft Stand und Perspektiven, Proceedings FNR/KTBL-Kongress, 10-11 Sept 2013, Kassel, Kuratorium für Technik und Bauwesen in der Landwirtschaft (KTBL). Schrift 501, Darmstadt, ISSN 978-3-941583-82-5:214-224

102. Wolf C, Gaida D, Bongards M (2012) Geeignete Online-Messtechnik zur Optimierung und Regelung von Biogasanlagen. In: 2. VDI-Konferenz 'Prozessmesstechnik an Biogasanlagen'. Verein Deutscher Ingenieure (VDI), Düsseldorf, pp 109-115, ISBN 978-3-942980-99-9

103. Wolf C, Gaida D, Bongards M (2013) Steuerungs- und Regelungskonzepte für landwirtschaftliche Biogasanlagen. In: Biogas in der Landwirtschaft Stand und Perspektiven, Proceedings FNR/KTBL-Kongress, 10-11 Sept 2013, Kassel, Kuratorium für Technik und Bauwesen in der Landwirtschaft (KTBL). Schrift 501, Darmstadt, ISSN 978-3-941583-82-5:225-234

104. Strobl M, Keymer U (2006) Technical and economical operating figures of agricultural biogas plants. Landtechnik 61(5/2006):266-267

105. Djatkov D, Effenberger M, Lehner A, Martinov M, Tesic M, Gronauer A (2012) New method for assessing the performance of agricultural biogas plants. Renewable Energy 40(1):104-112

106. Effenberger M, Bachmaier H, Kränsel E, Lehner A, Gronauer A (2010) Wissenschaftliche Begleitung der Pilotbetriebe zur Biogasproduktion in Bayern. LfL Schriftenreihe 1/2010, Freising, ISSN 1611-4159
107. Schönberg $\vee$, Busch G (2012) Steigerung des Methangehaltes durch biologische Wasserstoffumsetzung. Bornim Agrartechn Ber 79:66-75, ISSN 0947-7314

108. Luo G, Angelidaki I (2012) Integrated biogas upgrading and hydrogen utilization in an anaerobic reactor containing enriched hydrogenotrophic methanogenic culture. Biotech Bioeng 109(11):2729-2736

109. Reinhard G (2013) Wie viel Biogas (ver-)trägt die Region? In: Biogas in der Landwirtschaft - Stand und Perspektiven, Proceedings FNR/KTBL-Kongress, 10-11 Sept 2013, Kassel, Kuratorium für Technik und Bauwesen in der Landwirtschaft (KTBL). Schrift 501, Darmstadt, ISSN 978-3-941583-82-5:301-309

doi:10.1186/2192-0567-4-10

Cite this article as: Lebuhn et al:: Agricultural biogas production in Germany - from practice to microbiology basics. Energy, Sustainability and Society 2014 4:10.

\section{Submit your manuscript to a SpringerOpen ${ }^{\odot}$ journal and benefit from:}

- Convenient online submission

- Rigorous peer review

- Immediate publication on acceptance

- Open access: articles freely available online

- High visibility within the field

- Retaining the copyright to your article

Submit your next manuscript at $>$ springeropen.com 